\title{
Linking mineral deposits to speleogenetic processes in Cova des Pas de Vallgornera (Mallorca, Spain)
}

\author{
Bogdan P. Onac ${ }^{1, *}$, Joan J. Fornós ${ }^{2}$, Antoni Merino ${ }^{3}$, Joaquín Ginés ${ }^{4}$, and Jacqueline Diehl \\ ${ }^{1}$ School of Geosciences, University of South Florida, 4202 E. Fowler Ave., NES 107, Tampa, FL 33620 USA \\ ${ }^{2}$ Departament de Ciències de la Terra. Universitat de les Illes Balears, Ctra. de Valldemossa km 7.5. 07122 Palma de Mallorca, Illes Balears, Spain \\ ${ }^{3}$ Grup Espeleològic de Llubí, FBE, Illes Balears, Spain \\ ${ }^{4}$ Federació Balear d'Espeleologia. C/ Uruguai s/n, Palma Arena. 07010 Palma de Mallorca, Illes Balears, Spain
}

\begin{abstract}
Cova des Pas de Vallgornera (CPV) is the premier cave of the Balearic Archipelago. Over $74 \mathrm{~km}$ of passages develop within two carbonate lithofacies (reef front and back reef), which ultimately control the patterns of the cave and to some degree its mineral infilling. The diversity of speleothem-forming minerals is four times greater around or within hypogenerelated features (vents, rims, cupolas), compared to any other vadose passages in the cave. The mineralogy of speleothems (crusts, nodules, crystals, earthy masses) associated with hypogene features in the seaward upper maze of Sector $F$ is characterized by the presence of aragonite, ankerite, huntite, clay minerals, and quartz. In the Tragus and Nord sectors, however, the dominant mineral is dolomite, along with aragonite, celestine, huntite, clay minerals, and quartz. Calcite is by far the most ubiquitous mineral throughout the cave. Detailed macroscopic and scanning electron microanalysis and imaging have permitted the investigation of textural relationships between the minerals associated with vents, rims, and vent's roof and walls. These studies along with morphological and stable isotope analyses confirm that not all minerals are connected with a hypogene stage in the cave evolution, and furthermore, none of them appears to be sulfuric acid by-products. Instead, the mineral assemblages documented in speleothems from CPV clearly support at least three speleogenetic pathways, namely seacoast mixing, ascending of warm groundwaters, and meteoric recharge (vadose). Thus, cave minerals in Cova des Pas de Vallgornera hold the keys to reconstruction and understanding of processes and conditions under which they precipitated, allowing to establish their relationship with various speleogenetic pathways.
\end{abstract}

Keywords: $\quad$ cave minerals; speleogenesis; littoral caves; stable isotope; Mallorca

Received 10 March 2014; Revised 23 April 2014; Accepted 25 April 2014

Citation: Onac B.P., Fornós J.J., Merino A., Ginés J. and Diehl J., 2014. Linking mineral deposits to speleogenetic processes in Cova des Pas de Vallgornera (Mallorca, Spain). International Journal of Speleology, 43 (2), 143-157. Tampa, FL (USA) ISSN 0392-6672 http://dx.doi.org/10.5038/1827-806X.43.2.4

\section{INTRODUCTION}

Distinguishing hypogenic (source of aggressiveness stem beneath surface; groundwater recharge mainly follows ascending paths) from epigenic (dissolution caused by acids originating from surface or near-surface processes; meteoric recharge by diffuse or floodwater flow) caves is not always straightforward. This is mainly because the hydrologic settings under which they form are responsible, sometimes, for rather similar cave patterns (maze) and morphological features (solution pockets, cupolas, spongework; Ford \& Williams, 2007; Palmer, 2007, 2011; Klimchouk, 2009). The most common cave patterns displayed by hypogenic caves (i.e., sulfuric acid or thermal) includes spongework and network mazes, irregular chambers, and vertical to sub-vertical rising conduits. A suite of morphologies generated by rising flow (i.e., feeders, wall and ceiling features, etc.) appears to be indicative for hypogenic basal recharge (Klimchouk, 2009). Throughout this paper, a feeder represents a connecting karst conduit (between two or more levels of the cave) viewed in the direction of ascending flow. Instead, when using the term vent we refer to the aperture of feeders in floor passages (i.e., the outlet where the water and/or hot air was/is emerging), around which a mineral rim commonly occur.

Apart from these very peculiar large- and small-scale cave morphologies attributed to rising flow, a growing body of mineralogical studies indicates the existence of a clear relationship between various hypogene speleogenetic pathways and the minerals hosted within those respective caves (Hill \& Forti, 1997 and references therein; Onac \& Forti, 2011a, b). By far, the most 
complex, although expected, mineral assemblages were described from sulfuric acid caves (Hill, 1987; Polyak \& Provencio, 2001; Onac et al., 2007, 2009, 2011, 2013; Plan et al., 2012; Audra et al., 2013; Puşcaş et al., 2013; Sauro et al., 2014). The reason for this situation is the presence of sulfuric acid produced by oxidation/ hydrolysis of $\mathrm{H}_{2} \mathrm{~S}$-rich solutions that react with cave sediments and bedrock to form primary or secondary speleogenetic by-products (Polyak \& Provencio, 2011).

The leading speleogenetic processes responsible for producing the so-called thermal caves are mixing (thermal and meteoric water), cooling (thermal water becomes more aggressive as it cools while rising to surface), and condensation corrosion (Dublyansky, 2000, 2012). Although less abundant and diverse when compared to the sulfuric acid caves, the mineralogy of thermal cavities has certain characteristics; among them, the presence of tabular barite and celestine crystals, as well as quartz, opal, or chalcedony that coat or even replace cave bedrock walls (Takácsné Bolner, 1989; Leél-Őssy et al., 2011).

Cave development in the coastal zone is complex and often occurs during multiple sea-level changes (Mylroie, 2013; van Hengstum et al., 2014). The primary mechanism in control of forming these caves is the dissolution caused by mixing of two water bodies (fresh and salt) with contrasting temperature, chemistry, salinity, or $\mathrm{CO}_{2}$ content (Herman et al., 1985; Mylroie \& Carew, 1990). This particular type of caves form in shallow or deep coastal mixing zones and are characterized by spongework or crude ramifying passages. The littoral caves of Mallorca also features breakdown chambers and rectilinear karst conduits (Ginés et al., 2013, 2014). In general, the sea coast mixing caves have a narrow range of minerals composing their speleothems. Although the bedrock composition is monotonous, there are a few exceptional littoral caves that host very interesting and unusual mineral assemblages (Onac et al., 2001, 2008, 2014; Merino et al., 2009; Fornós et al., 2011). What ultimately controls the mineral diversity in these caves, is the particular geochemical environment of the mixing zone, where the carbonate bedrock is exposed to brackish groundwater.

Most of the studies investigating cave minerals rely on traditional X-ray diffraction (XRD), scanning electron imaging, X-ray fluorescence (XRF), and chemical composition inspection using microprobe, energydispersive X-ray spectroscopy (EDS), or inductively coupled plasma mass spectrometry (ICP-MS) techniques. The use of $\delta^{34} \mathrm{~S}$ in tracing the source of $\mathrm{S}$ in cave minerals was pioneered by Hill (1981) and Kirkland (1982), whereas van Everdingen et al. (1985) first investigated the $\delta^{18} \mathrm{O}$ in sulfates to show the origin of $\mathrm{O}$ (meteoric $\mathrm{H}_{2} \mathrm{O}$ or atmospheric $\mathrm{O}_{2}$ ). Over the last decade, stable isotope analyses (mainly $\delta^{13} \mathrm{C}, \delta^{18} \mathrm{O}, \delta^{34} \mathrm{~S}$ ) on cave minerals come to be a routine investigation in distinguishing between different speleogenetic pathways (Dublyansky, 1997; Onac et al., 2007, 2009, 2011; Palmer \& Palmer, 2012; Temovski et al., 2013; Sauro et al., 2014a, b).

The present paper reports on the CPV mineral inventory, discusses the origin of the unusual species with respect to their occurrence within the cave (i.e., Sector F, Tragus and Nord sectors), and makes an attempt to link the mineral assemblages to various speleogenetic pathways identified and discussed by Ginés et al. (2014).

\section{GEOLOGIC AND KARST SETTINGS}

Cova de Pas de Vallgornera is the most significant (morphologically, scientifically, and length-wise) karst feature of Mallorca (Merino et al., 2011, 2014a, b; Ginés et al., 2014). Its artificial entrance opens on the southern coast of the island and gives access to an extensive 2-D spongework maze and fracturecontrolled angular passages, currently exceeding $74 \mathrm{~km}$ of development (for cave location see Fig. 1 in Merino et al., 2014a). There is a clear relationship between geologic setting and cave patterns in that the 2-D spongework passages and collapse chambers develop in the more porous reef front facies of Upper Miocene age, whereas the angular galleries are typical for the outer lagoon facies (calcarenites and calcisiltites; Fig. 1) (Ginés et al., 2014). As highlighted in this paper, a similar relationship holds true for the mineral assemblages. For additional information on the geologic and karst settings of this cave, readers are directed to the publications of Ginés \& Ginés (2007), Ginés et al. (2009), Fornós et al. (2011), Merino et al. (2011), as well as those included in this special issue of the International Journal of Speleology.

The geothermal studies conducted over the last decade in Mallorca pointed out the existence of at least two aquifers with anomalous temperatures in the vicinity of CPV (Mateos et al., 2005). The major thermal aquifer is hosted at depth in limestone and breccia of Lower Jurassic age (López, 2008; Fig. 1). Pools with thermal waters $\left(23\right.$ to $\left.27^{\circ} \mathrm{C}\right)$ are presently known in the lowermost parts of Cova de sa Guitarreta and Pou de Can Carro, two vertical caves located just few $\mathrm{km} \mathrm{NE}$ of CPV (Merino et al., 2011). The water pooling in these caves is related to the shallow unconfined aquifer hosted within the Reef

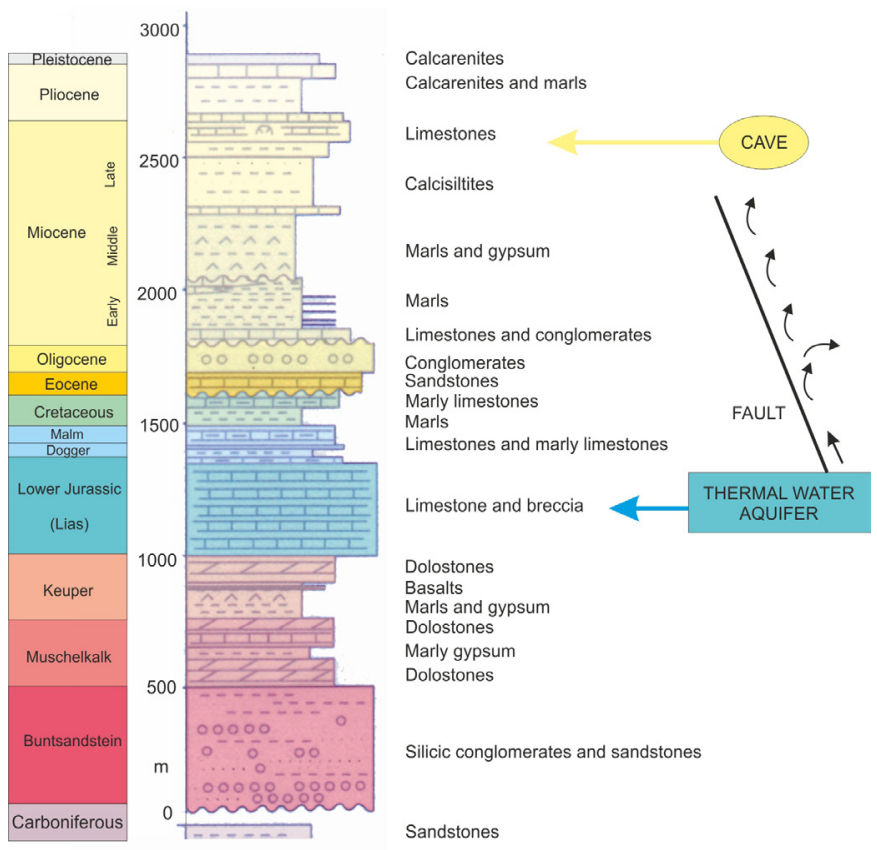

Fig. 1. Lithostratigraphical column showing the position of Cova des Pas de Vallgornera in the Upper Miocene unit and the Lower Jurassic thermal aquifer (modified Fornós \& Gelabert, 1995; Mateos et al., 2005). 
Complex, in which hot water from the deep thermal aquifer migrates along a NE-SW fracture (Mateos et al., 2005).

\section{SAMPLES AND METHODS}

More than 100 mineral samples were collected over the last six years during exploration and survey expeditions or at times of dedicated mineralogical cave trips. Samples were acquired mainly from the landward passages of Tragus and Nord sectors (71), but also from the seaward upper maze of Sector F (37) (Fig. 2), both developed within back reef facies limestone. The sampling activities focused on speleothems associated with hypogene-related features, such as vents and rims (Fig. 3a, b) or within feeders (Fig. 3c) located along the above mentioned sections of the cave.

All investigated samples (108) on which this paper relies, received a thorough macroscopic characterization at the time of collection in the cave and were later examined under the binocular microscope. The identification of minerals is primarily based on X-ray diffraction (XRD). The samples were all air-dried in the laboratory, and clay and other detritus was then removed. An agate mortar was employed for grinding the handpicked subsamples down to a fine powder (less than $38 \mu \mathrm{m}$ in size particles) before running them on a Siemens D5000 diffractometer (Serveis Cientificotècnics, University of Balearic Islands in Palma de Mallorca, Spain) equipped with a diffracted-beam graphite monochromator and operated at $40 \mathrm{kV}$ and $30 \mathrm{~mA}$. Digitally recorded patterns were collected between 3 and $80^{\circ} 2 \theta$ (step size of $0.04^{\circ} 2 \theta$ and count rate of 2 to 4 second/step) and analyzed using EVA software (version 8.0). Silicon (NBS 640b) was used as the internal standard. Additional mineralogical analyses were performed in the Department of Chemistry,

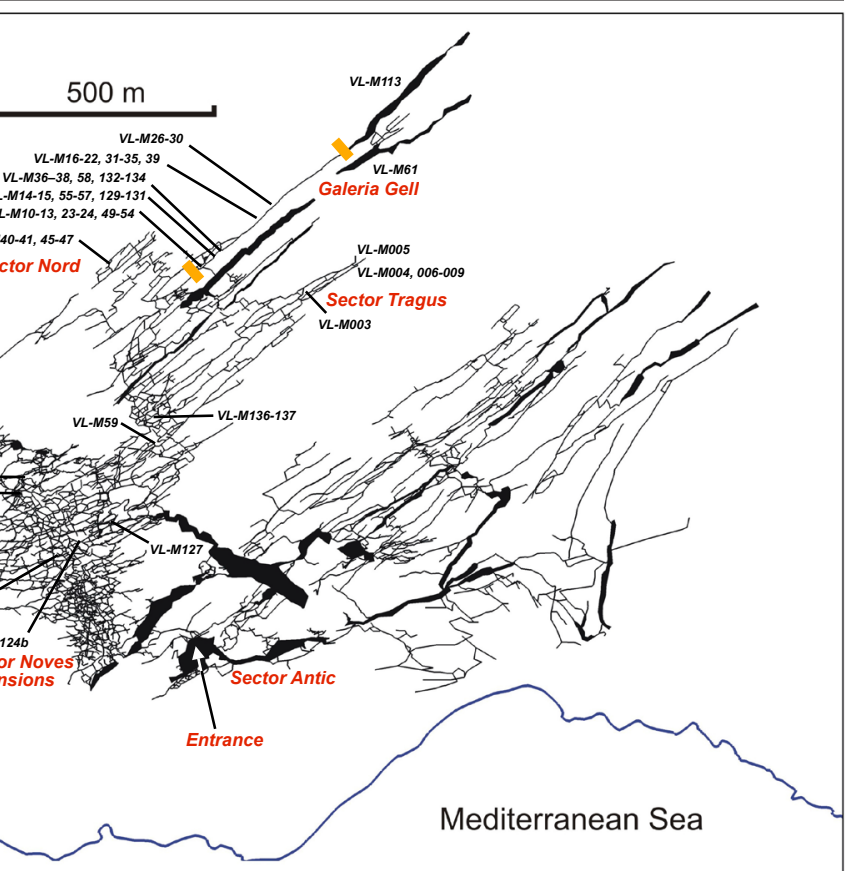

Fig. 2. Location of the mineral samples on the map of CPV. The two orange lines across e the cross-section in Fig. 3.

University of South Florida using a Bruker Analytical X-Ray System, Inc. D8 Endeavor XRD. Samples were scanned from $5^{\circ}$ to $75^{\circ} 2 \theta$ with a step increment of $0.02^{\circ}$, a scan speed of $0.5 \mathrm{sec} / \mathrm{step}$ (analytical conditions: $50 \mathrm{kV}, 40 \mathrm{~mA}$, CuKa radiation, line source filtered with a $\mathrm{Ni}$ foil). Mineral identification and abundance was evaluated quantitatively (in few samples) by measuring the integrated intensity of the strongest peak in each phase and then, using the reference intensity ratio (RIR) these intensity values were converted into weight percent (Hubbard \& Snyder, 1998). The overall results based on XRD identification are tabulated in Table 1.

For scanning electron microscope (SEM) observations, freshly fractured speleothem fragments or hand-picked aggregates were gold-coated for better results while performing the semi-quantitative chemical analyses. SEM investigations were made at the University of Balearic Islands on a Hitachi
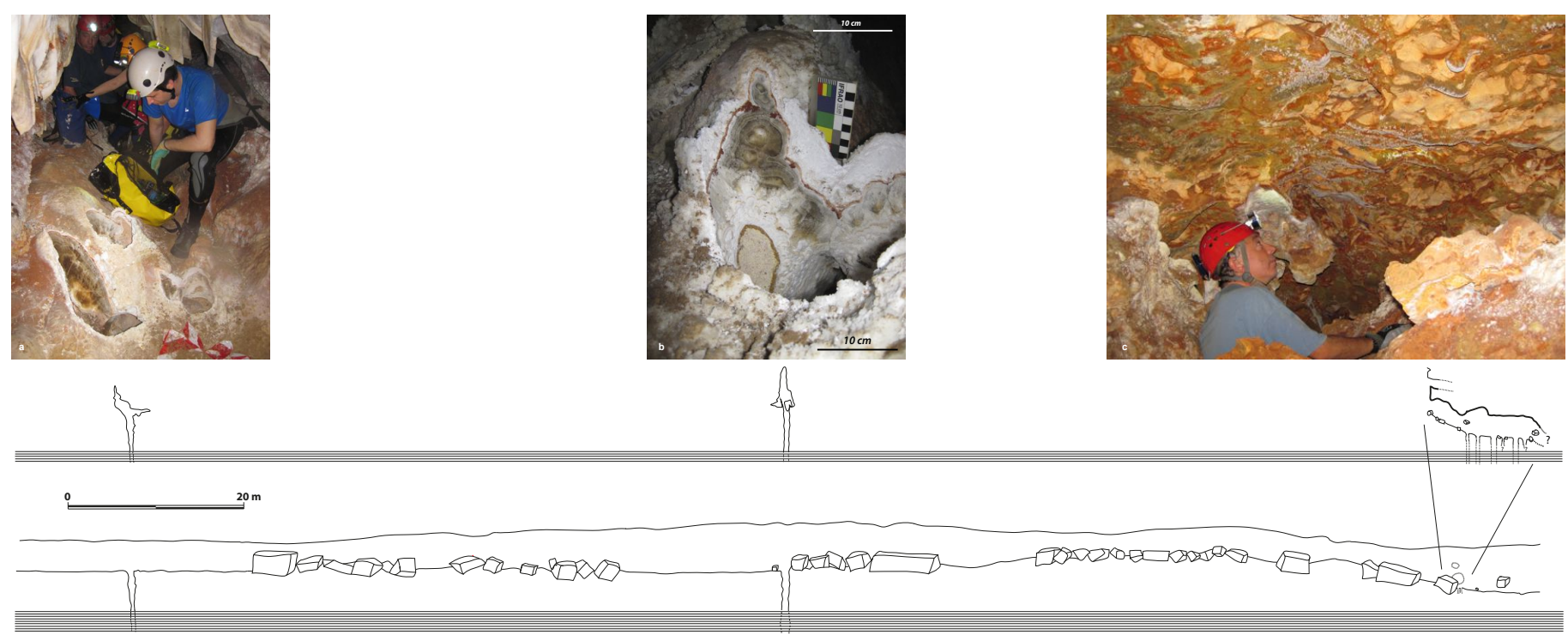

Fig. 3. Cross-section along Tragus Gallery showing the position of floor feeders (vents); a-b) vents (holes in the floor connecting different cave levels; scale bar $=10 \mathrm{~cm}$ ) and rims (the projecting white mineral fringe); c) multicolored ceiling deposit above a complex vent. 
Table 1. List of minerals identified in speleothems from Cova des Pas de Vallgornera and their possible origin. Minerals are divided by their location in two major areas of the cave and further sorted based on the number of occurrences around or within hypogene features or vadose settings.

\begin{tabular}{|c|c|c|c|c|c|}
\hline \multirow{2}{*}{ Mineral and Chemical formula ${ }^{1}$} & \multicolumn{2}{|c|}{ Sector $F$} & \multicolumn{2}{|c|}{ Tragus and Nord sectors } & \multirow{2}{*}{ Origin $^{2}$} \\
\hline & Hypogene & Vadose & Hypogene & Vadose & \\
\hline Ankerite, $\mathrm{Ca}\left(\mathrm{Fe}^{2+}, \mathrm{Mg}\right)\left(\mathrm{CO}_{3}\right)_{2}$ & 6 & 1 & 3 & 3 & $\mathrm{bb}, \mathrm{v}$ \\
\hline Aragonite, $\mathrm{CaCO}_{3}$ & 12 & - & 12 & 3 & $h w, v, b b$ \\
\hline Barite, $\mathrm{Ba}\left(\mathrm{SO}_{4}\right)$ & 4 & - & 1 & 1 & hw \\
\hline Braunite, $\mathrm{Mn}^{2+} \mathrm{Mn}_{6}^{3+} \mathrm{SiO}_{12}$ & - & - & 1 & 1 & $\mathrm{hw}, \mathrm{bw}$ ? \\
\hline Brushite, $\mathrm{Ca}\left(\mathrm{PO}_{3} \mathrm{OH}\right) \cdot 2 \mathrm{H}_{2} \mathrm{O}$ & - & - & - & 1 & $\mathrm{v}$ \\
\hline Calcite, $\mathrm{CaCO}_{3}$ & 24 & 1 & 26 & 4 & $v, b b$ \\
\hline Celestine, $\mathrm{SrSO}_{4}$ & - & 1 & 8 & 1 & hw \\
\hline Chamosite, $\left(\mathrm{Fe}^{2+}, \mathrm{Mg}, \mathrm{Al}, \mathrm{Fe}^{3+}\right)_{6}(\mathrm{Si}, \mathrm{Al})_{4} \mathrm{O}_{10}(\mathrm{OH}, \mathrm{O})_{8}$ & - & - & 1 & - & hw? bw $( \pm \mathrm{m})$ \\
\hline Cristobalite, $\mathrm{SiO}_{2}$ & - & - & 1 & - & hw, bw \\
\hline Dolomite, $\mathrm{CaMg}\left(\mathrm{CO}_{3}\right)_{2}$ & 3 & 1 & 15 & 4 & $\mathrm{v}, \mathrm{bb}( \pm \mathrm{m})$ \\
\hline Epsomite, $\mathrm{Mg}\left(\mathrm{SO}_{4}\right) \cdot 7 \mathrm{H}_{2} \mathrm{O}$ & - & - & - & 1 & $\mathrm{v}, \mathrm{bb}$ ? \\
\hline Gibbsite, $\mathrm{Al}(\mathrm{OH})_{3}$ & - & - & 1 & - & hw \\
\hline Goethite, $\mathrm{FeO}(\mathrm{OH})$ & 2 & - & - & 2 & $\mathrm{v}$ \\
\hline Gypsum, $\mathrm{Ca}\left(\mathrm{SO}_{4}\right) \cdot 2 \mathrm{H}_{2} \mathrm{O}$ & - & 3 & 3 & 4 & $h w, v, b b$ \\
\hline Jacobsite, $\mathrm{Mn}^{2+} \mathrm{Fe}^{3+}{ }_{2} \mathrm{O}_{4}$ & 1 & - & 1 & 1 & hw, bw? \\
\hline Hematite, $\mathrm{Fe}_{2} \mathrm{O}_{3}$ & - & - & 5 & 1 & $\mathrm{v}$ \\
\hline Huntite, $\mathrm{CaMg}_{3}\left(\mathrm{CO}_{3}\right)_{4}$ & 5 & - & 6 & - & $\mathrm{v}$ \\
\hline Illite (series) $)^{\S}, \mathrm{K}_{0.65} \mathrm{Al}_{2.0} \square \mathrm{Al}_{0.65} \mathrm{Si}_{3,35} \mathrm{O}_{10}(\mathrm{OH})_{2}$ & 5 & - & 2 & - & bw $( \pm \mathrm{m})$ \\
\hline Kaolinite, $\mathrm{Al}_{2} \mathrm{Si}_{2} \mathrm{O}_{5}(\mathrm{OH})_{4}$ & 4 & 1 & 9 & 3 & bw $( \pm \mathrm{m})$ \\
\hline 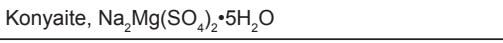 & - & - & - & 1 & $\mathrm{v}$ \\
\hline Montmorillonite, $(\mathrm{Na}, \mathrm{Ca})_{0.3}(\mathrm{Al}, \mathrm{Mg})_{2} \mathrm{Si}_{4} \mathrm{O}_{10}(\mathrm{OH})_{2} \cdot \mathrm{nH}_{2} \mathrm{O}$ & 3 & 1 & 3 & 1 & $\mathrm{bw}( \pm \mathrm{m})$ \\
\hline Nordstrandite, $\mathrm{Al}(\mathrm{OH})_{3}$ & - & - & 1 & - & hw \\
\hline Quartz (low), $\mathrm{SiO}_{2}$ & 6 & 1 & 11 & 4 & hw. bw \\
\hline Romanèchite, $\left(\mathrm{Ba}, \mathrm{H}_{2} \mathrm{O}\right)_{2}\left(\mathrm{Mn}^{4+}, \mathrm{Mn}^{3+}\right)_{5} \mathrm{O}_{10}$ & - & - & - & 1 & bw $( \pm \mathrm{m})$ \\
\hline Strontianite, $\mathrm{Sr}\left(\mathrm{CO}_{3}\right)$ & - & - & 1 & - & hw \\
\hline Todorokite, $(\mathrm{Na}, \mathrm{Ca}, \mathrm{K}, \mathrm{Ba}, \mathrm{Sr})_{1-x}(\mathrm{Mn}, \mathrm{Mg}, \mathrm{Al})_{6} \mathrm{O}_{12} \cdot 3-4 \mathrm{H}_{2} \mathrm{O}$ & 1 & - & 1 & 2 & $\mathrm{hw}( \pm \mathrm{m})$ \\
\hline
\end{tabular}

${ }^{1}$ According to the official IMA-CNMNC list of minerals (http://pubsites.uws.edu.au/ima-cnmnc/imalist.htm). ${ }^{2} \mathrm{hw}$ : hot water; v: vadose; bw: bedrock weathering; bb: bedrock/brackish water interface; $\pm \mathrm{m}$ : microbial $\S$ According to Rieder et al. (1998).

S-3400N using a backscattered electron detector (BSE) for atomic-number contrast imaging. The operation parameters were high-vacuum, $15 \mathrm{kV}, 5$ to $10 \mathrm{nA}$, and a defocussed electron-beam diameter of $30 \mu \mathrm{m}$. Further chemical analyses on bedrock samples were conducted in the Center for Geochemical Research (School of Geosciences, University of South Florida) using a Perkin-Elmer Elan DRC II Quadrupole Inductively Coupled Plasma Mass Spectrometer.

The $\delta^{34} \mathrm{~S}$ ratios of 11 samples representing S-bearing minerals (barite, celestine, and epsomite) were measured on a Delta V Isotope Ratio Mass Spectrometer (IRMS) coupled with an Elemental Analyzer Costech ECS 4100 at the School of Geosciences Stable Isotope Lab (University of South Florida) following the method described in Grassineau et al. (2001). The results reported in standard $\delta$-notation were normalized to $\mathrm{CDT}$ (Cañon Diablo Troilite) using $\delta^{34} \mathrm{~S}$ values of four IAEA standards (IAEA, International Atomic Energy Agency, S-2 and S-3 for sulfides and SO-5 and SO-6 for sulfates). The reproducibility between replicate standards in each run was better than $\pm 0.1 \%$ o $(1 \sigma)$. Selected speleothems collected from vents and rims and around these features and three bedrock samples (two from reef front and one from back reef limestone) were analyzed for oxygen and carbon isotopic ratio in $\mathrm{CO}_{2}$ expelled after reacting the samples for 24 hours (or 5 days for ankerite) with $103 \% \mathrm{H}_{3} \mathrm{PO}_{4}$ at $25^{\circ} \mathrm{C}$. The isotopic ratios were measured on the same IRMS instrument, but the values are reported in $\delta \%$ o relative to the PDB (Pee Dee Belemnite) standard. For accuracy control, NBS-18 and NBS-19 were used as internal laboratory standards. Reproducibility was better than $\pm 0.12 \%$.

\section{RESULTS AND DISCUSSION}

Twenty-six minerals were identified throughout the cave (Table 1); the highest diversity (20 species) is around or inside typical hypogene features (although not all minerals are necessary related to a hypogene speleogenetic phase) occurring within back reef limestone in the Tragus and Nord sectors (see Fig. 3). In the upper maze of Sector F (seaward part) which also develops on back reef facies only 13 minerals occur. At all these locations they form either monomineral speleothems (spar, crusts, coatings, powder, moonmilk) or multi-mineral associations (especially in the abundant corrosion residues overlying the walls and ceilings). We note an even larger mineralogical contrast in the composition of speleothems that are unrelated to hypogene features; nineteen are deposited in galleries and chambers developed in Tragus and Nord sectors whereas only eight in Sector F. Examining the occurrences of all minerals identified, their crystal morphology, and the 
relationship between various species at each location, we distinguish three groups: 1) minerals related to hypogene speleogenetic processes, 2) minerals precipitated at the bedrock/brackish water interface, and 3) minerals of vadose/epiphreatic origin, typical for low-temperature epigenetic caves. A few species (e.g., aragonite, celestine, barite, gypsum, todorokite, etc.) belong to either group 1 and 3 or 2 and 3 , but only aragonite and gypsum precipitate under all three minerogenic settings. The most abundant or peculiar minerals of these groups are characterized below; those having multiple origins are presented only under one of the genetic categories.

\section{Minerals related to hypogene speleogenetic processes}

In $\mathrm{CPV}$, the minerals framed within this category are related to: i) either direct subaerial precipitation of dissolved species transported per ascensum by warm solutions (hw in Table 1) or ii) replacement/ weathering of the bedrock (bw) due to corrosion when warm, humid air originating from these warm waters condensed onto the cold cave walls. This latter process might be enhanced/controlled by microbial activity [bw $( \pm \mathrm{m})$ ]. Although there are no documented thermal water pools per se in CPV, the abundance of vents (characterized by rich mineral assemblages) suggests hypogene (thermal water-related) basal recharge was common in many parts of the cave at various times during its evolution (Ginés et al., 2009; Fornós et al., 2011; Ginés et al., 2014).

\section{Barite \& Celestine}

Barite occurs as patchy crusts (few centimeters across) covering either bedrock or other coatings in and around hypogene features located in Sector F. At these locations barite appears as tabular after $\{001\}$ closely associated with dolomite (Fig. 4a) and prismatic (after [010] and [100]) or bladed crystals (sometimes massive aggregates) along with acicular aragonite (Fig. 4b). It was also found precipitated on top of calcite and/or ankerite aggregates (see discussion under ankerite entry).

Celestine appears as bouquets of sub-centimeter long colorless to light blue shaded crystals (Fig. 4c) in eight occurrences, all related to hypogene features hosted within cave passages developed in Tragus and Nord sectors. SEM investigation reveals euhedral to subhedral equant prismatic crystals formed by the development of $\{011\},\{001\}$, and $\{210\}$; another crystal habit observed is pyramidal with $\{122\},\{011\}$, or $\{102\}$ (Fig. 4d, e).

There is only one location in the Tragus Gallery (Aragonite Tub section) where the two minerals are closely associated and were precipitated over and in between $\sim 1$ million year old (Polyak, pers. comm.) aragonite needles (Fig. 4f). Based on the relationship between the two sulfates and their host mineral (aragonite) and considering that barite and celestine form a solid solution, we believe they precipitated from per ascensum migrating strontium- and baritebearing hot groundwater after the thick aragonite crust covered the cave passage at this particular location. Considering the average $\delta^{34} \mathrm{~S}$ values obtained on these

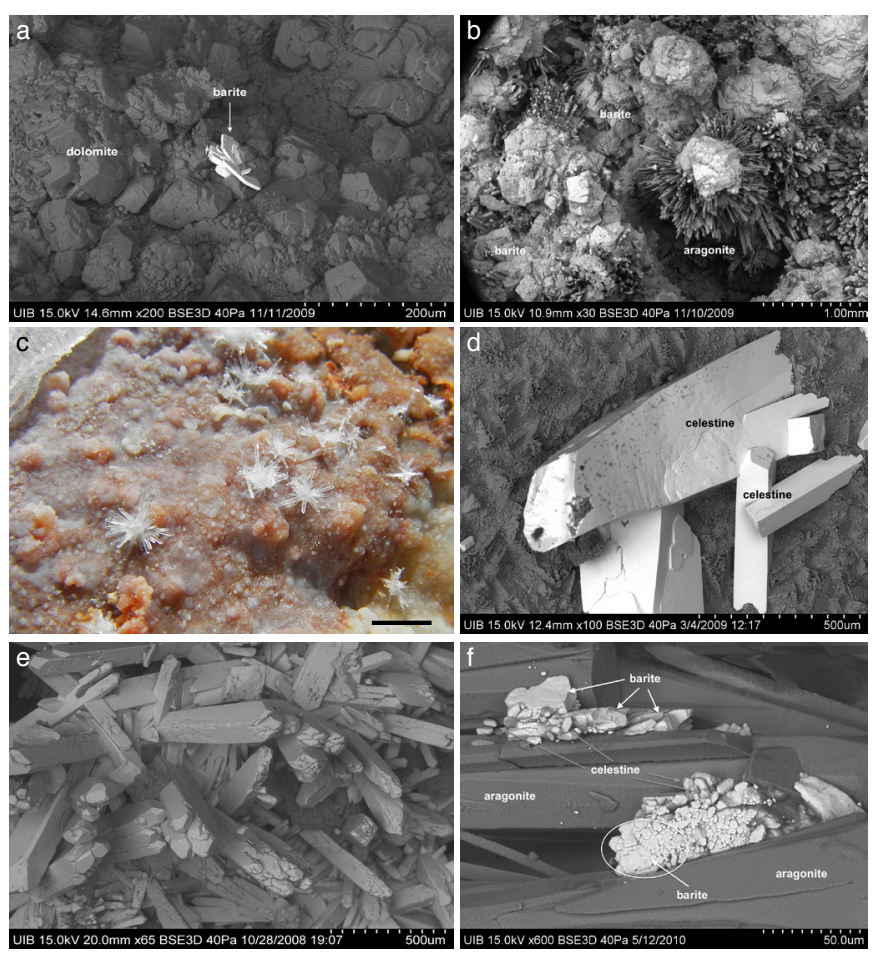

Fig. 4. BSE and hand specimen microphotographs. a) Tabular crystals of barite precipitated over dolomite; b) Granular aggregates of barite covered by long prismatic crystals of aragonite; c) Light blue bouquets of celestine crystals over either dolomite or gypsum crusts; d-e) Crystals of celestine displaying subhedral and pyramidal morphologies; f) Tabular, prismatic, and granular aggregates of barite and celestine precipitated in a late-stage over prismatic crystals of aragonite.

two sulfates $(+21.6 \%$ o for barite $(n=3)$ and $+21.7 \%$ o for celestine ( $\mathrm{n}=5$ ), respectively) it is obvious that it derived from dissolution of primary marine sulfate (average $\delta^{34} \mathrm{~S}$ values of Miocene seawater sulfate is 22\%o; Paytan et al., 1998) interbedded or existing within limestones and is not a by-product of sulfuric acid speleogenesis.

\section{Chamosite}

Chamosite is a monoclinic mineral of the chlorite group first time identified in a cave environment. It occurs within the red fluffy ceiling deposit above a vent on Tragus Gallery. It is closely associated with quartz, hematite, braunite, kaolinite, and montmorillonite. It was identified by means of XRD (peak at $7.05 \AA$ that vanished after digesting the sample in concentrated $\mathrm{HCl}$ ) and subsequently confirmed by SEM-EDS microchemical analyses. The crystals are tabular $\{001\}$ arranged in the shape of sheafs (Fig. 5), < $100 \mu \mathrm{m}$ across and are flattened on (001).

Vallgornera is an unusual occurrence of chamosite and the following two scenarios seem plausible to explain its presence: i) authigenically formed under slightly acidic to slightly alkaline conditions $(\mathrm{pH} 5$ to 8). Under this model, hot air-condensing above feeders liberate (by corrosion) $\mathrm{Fe}^{2+}, \mathrm{Fe}^{3+}, \mathrm{Al}^{3+}$, and silica from the carbonate rock, which then co-precipitate with the subsequent formation of chamosite. Hence it is "secondary" in origin, thus a true cave mineral; ii) chamosite might have been a primary mineral in the carbonate rock (Akande \& Mücke, 1993) and became exposed by various weathering processes (including bacterial activity) that affected the bedrock. If so, chamosite would not be a true cave mineral. 


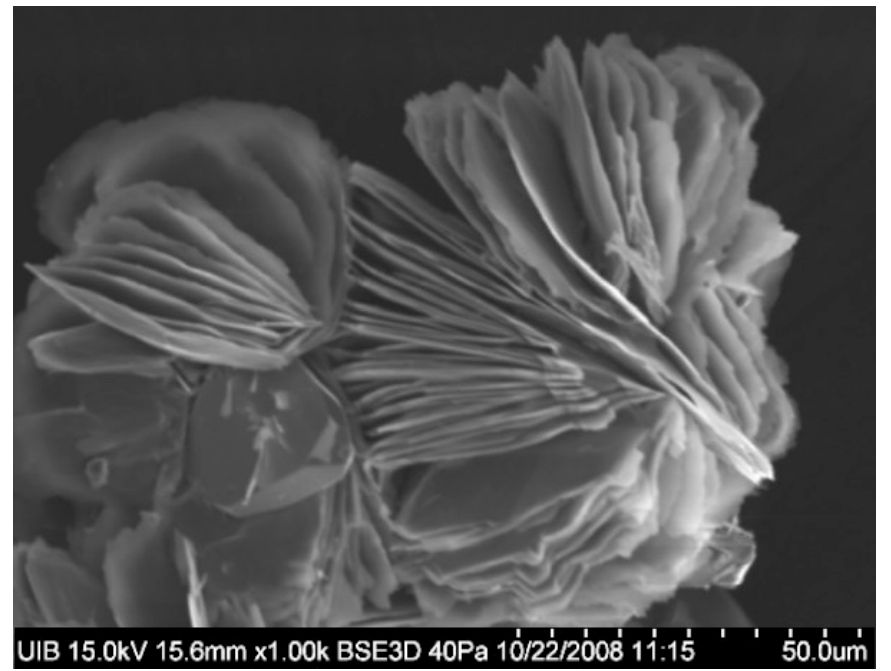

Fig. 5. Foliated and radiating crystals of chamosite.

However, crystal faces look fresh and unaffected by dissolution, suggesting an authigenic mineral. Further investigations are planned to confirm the exact origin of chamosite.

\section{Jacobsite}

This spinel-group mineral has been identified in three locations (two of them related to hypogene features) on both seaward (Sector F) and inner part (Tragus Gallery) of the cave. The samples we investigated occur as dark (brown to black), centimeter-thick deposits on a tube that is genetically related to a large floor feeder. Under SEM, jacobsite appears as coarse granular (Fig. 6a) to massive (Fig. 6b) crystals, 20 to $>100 \mu \mathrm{m}$ in length, showing no cleavage. It is closely associated with either quartz and calcite or clay minerals and calcite (Fig. 6).

Without having explored in greater detail the presence of this mineral in CPV, we assume it is a condensationcorrosion product of Mn-bearing minerals such as braunite and romanèchite. The ICP-MS analyses showed the manganese is present in both bedrock and water in concentrations in the order of up to $120 \mathrm{ppm}$. To our knowledge these are the first confirmed occurrences of jacobsite in a cave worldwide.

\section{Nordstrandite}

Nordstrandite was first described by Polyak \& Provencio (2001) from Lechuguilla Cave, interpreting its origin as the alteration product of alunite and halloysite-10Å. They assumed nordstrandite was possibly a speleogenetic by-product and subsequently,
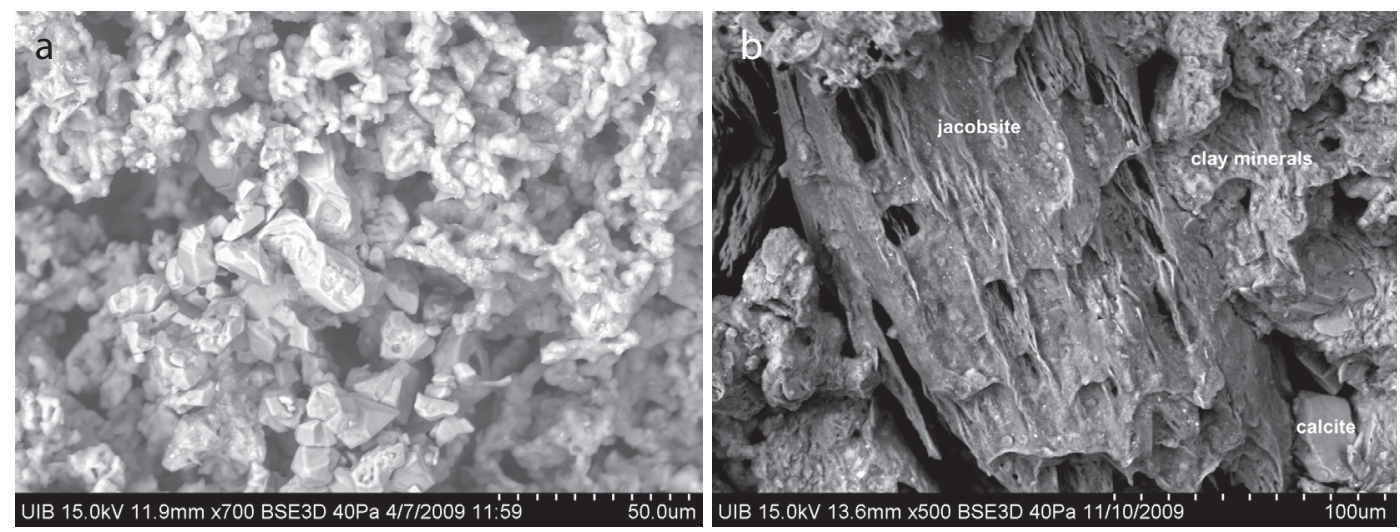

Fig. 6. Granular (a) and massive (b) aggregates of jacobsite. other authors considered its occurrence in caves as diagnostic for hypogene speleogenesis (Merino et al., 2009; Fornós et al., 2011).

The sample in which nordstrandite was positively identified consists of a millimeter-size thick brown film, collected from the ceiling of Tragus Gallery, above a feeder. The SEM observations reveal clay mineral aggregates and radiating clusters of tabular to prismatic crystals of nordstrandite, terminated by sharp, clear pyramidal faces (Fig. 7). The size of the crystals does not exceed 50-60 $\mu \mathrm{m}$ and they show perfect cleavage after $\{110\}$.

Given the environmental conditions from which nordstrandite was previously reported (outside the cave; Wall et al., 1962; Hathaway et al., 1965; Milton et al., 1975), its precipitation in CPV is a matter of conjecture. Based on the relationship between nordstrandite and the other minerals/deposits at the sampled location in the Tragus Gallery, it appears to be a late-stage precipitate. The exact chain of reactions that led to its deposition is still unclear. A carbonization mechanism, similar to the one proposed by Lipin (2001) seems reasonable, although it is difficult to imagine a limestone cave environment with $\mathrm{pH}$ above 13. However, nordstrandite was also obtained experimentally at lower $\mathrm{pH}$ (7.5 to 9) but under specific ionic concentrations and temperatures (Van Nordstrand et al., 1956). Not having such information for the CPV nordstrandite, we assume a combination of the two models cited above, with aluminous solutions transported into the cave by the hypogene hot waters or with $\mathrm{Al}^{3+}$ sourced from either limestone bedrock or clay minerals already present in the cave.

\section{Strontianite}

During one of the visits in CPV, a fragment of bedrock (within a rim around a vent) on which two distinct, transparent and translucent minerals occurred as tiny crystals was sampled. The XRD investigation clearly identified dolomite as well as the presence of celestine and gypsum (by their characteristic peaks). The BSE imaging and micro-chemical analysis confirmed these three minerals, but in addition, we noticed spiky, radiating clusters of long (60 to $80 \mu \mathrm{m}$ ) prismatic crystals [001] growing on top of botryoidal aggregates of dolomite (Fig. 8). The EDS micro-analyses revealed the presence of only three elements: $\mathrm{Sr}, \mathrm{C}$, and $\mathrm{O}$ that make up strontianite.

Due to some geochemical constraints (e.g., temperature- and $\mathrm{CO}_{2}$ partial pressure-dependent solubility, ion activity, $\mathrm{Sr} / \mathrm{Ca}$ ratios, and $\mathrm{pH}$; Helz \& Holland, 1965; Busenberg et al., 1984) in the $\mathrm{SrCO}_{3}-\mathrm{CO}_{2}-\mathrm{H}_{2} \mathrm{O}$ system, strontianite is an uncommon mineral in nature. There are only three reported cave occurrences from Sima de las Fumarolas, Spain (Fernández-Rubio et al., 1975), a small, nameless cave in the Terrace 


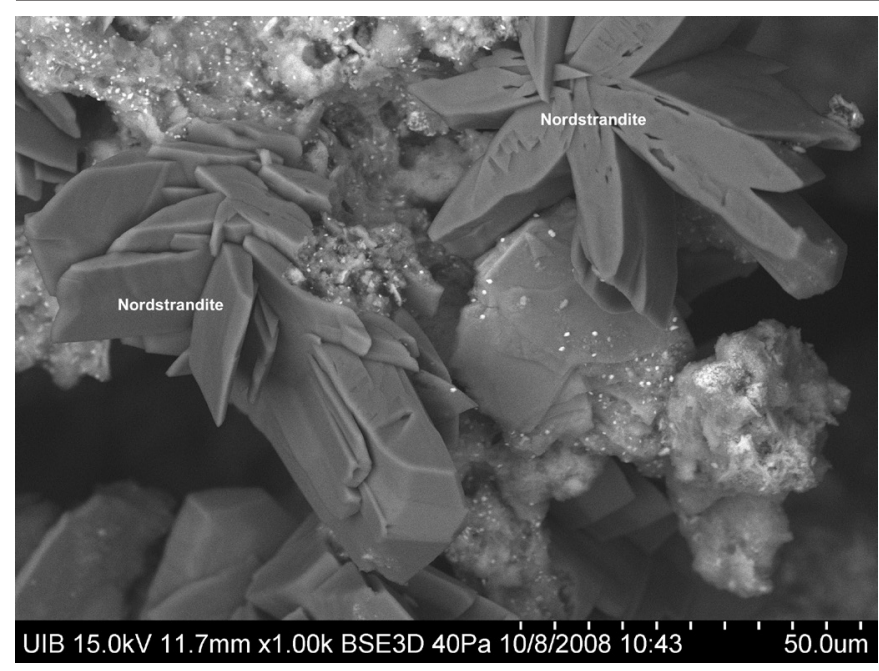

Fig. 7. BSE image of radiating clusters of tabular to prismatic crystals of nordstrandite. Note the pyramidal faces on some of the crystals.

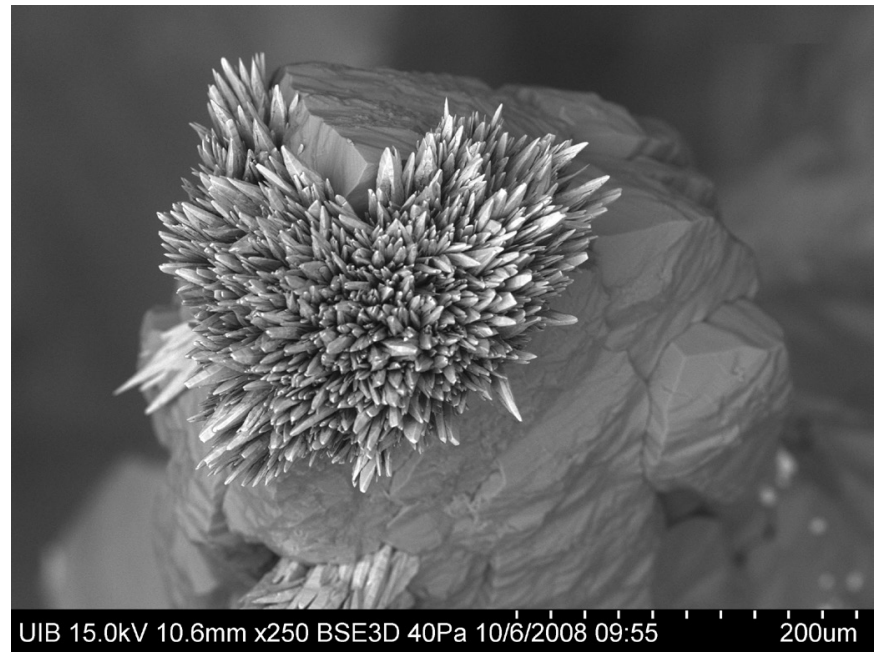

Fig. 8. Radiating clusters of short prismatic strontianite crystals developed over dolomite aggregates (BSE image).

Mountains, USA (Hill \& Forti, 1997), and Serizjan, Iran (Calaforra et al., 2013).

The mineral association that includes strontianite in CPV suggests a precipitation of this rare carbonate by cooling of $\mathrm{Sr}^{2+}$-rich ascending hot waters as they entered the cave. Strontium is likely derived from the leaching of nearby carbonate and evaporite beds. In order to precipitate strontianite, two other requirements need to be met: small concentrations or absence of sulfate anion and a high $\mathrm{Sr} / \mathrm{Ca}$ ratio (Calaforra et al., 2013). Having celestine and gypsum precipitated out of the solution in an early stage of minerogenesis consumes the majority of the available sulfate. Combining this sulfate deficit with an increase of the $\mathrm{Sr} / \mathrm{Ca}$ ratio due to cooling of the solution and precipitation of dolomite, may be responsible for localized deposition of strontianite. Microbialinfluenced accumulation of strontianite, following the mechanism proposed by Bonny and Jones (2003) cannot be ruled out.

\section{Minerals precipitated in the vicinity of bedrock/ brackish water interface}

A limited number of minerals (ankerite, aragonite, calcite, dolomite, epsomite, and gypsum) form speleothems near the contact between limestone and brackish water in CPV (bb in Table 1). The geochemical conditions under which aragonite, calcite, and gypsum speleothems are deposited in littoral caves at or a few centimeters below and above the present brackish water table are well documented and will not be discussed here (Bottrell et al., 1991; Onac et al., 2001, 2005; Csoma et al., 2006; Ginés et al., 2012). The phreatic overgrowths on speleothems (POS) used to reconstruct past sea-level positions (Vesica et al., 2000; Dorale et al., 2010; Tuccimei et al., 2010; Ginés et al., 2012) fall into this category as calcite and/or aragonite encrustations are precipitated over preexisting vadose speleothems from brackish waters. Dolomite is discussed along with the vadose minerals, thus ankerite and epsomite are the highlights of this group.

\section{Ankerite}

Ankerite was positively identified (XRD and SEMEDS) in millimeter-size microcrystalline crusts of various colors, from white to yellowish-brown or dark brown. Eight of the samples come from cave passages rich in hypogene features, whereas the other 4 samples were collected at vadose sites. Similar to dolomite, ankerite forms rhombohedral crystals $\{1011\}$ (Fig. $\overline{9}$ a) or pseudo-octahedral (Fig. 9b). Dissolution features (pits) are frequent on many crystal faces; another characteristic of the rhombohedral ankerite crystals is the stepped morphology along their edges and at corners (Fig. 9a). In sample VL-M101, ankerite is intergrown with calcite and closely associates with aragonite crystals elongated in the direction of [001] and flattened on (110) (Fig. 9b). Bright white prismatic barite crystals were observed under SEM (Fig. 9b). Given their relationship with the other mineral phases, it certainly precipitated in a late stage after calcite/ankerite were already deposited.

Apart from XRD, staining techniques, and chemical analysis, ankerite in sedimentary environments is commonly investigated using stable isotope geochemistry. However, oxygen isotope fractionation between water and ankerite at low-temperatures is poorly constrained (Zheng, 1999). Multiple oxygen and carbon isotopic analyses were performed on nine samples of both hypogene- and vadose-related speleothems collected above vents in Sector F and Tragus Gallery and along other vadose passages. The isotopic composition $\left(\delta^{13} \mathrm{C}\right.$ and $\left.\delta^{18} \mathrm{O}\right)$ of these samples is listed in Table 2. Plotted in Fig. 10 the data show two distinct populations with significantly different $\delta^{13} \mathrm{C}$ values $\left(\sim 10 \%\right.$ o), whereas the $\delta^{18} \mathrm{O}$ values are within $2 \%$. The ankerite crusts precipitated in conjunction with known hypogenic features group as Population 1 , which is characterized by relatively high $\delta^{13} \mathrm{C}(1.97$ to $2.04 \%$ ) and $\delta^{18} \mathrm{O}$ values between -4.71 and $-4.65 \%$ o (Fig. 10). The bedrock samples plot very close to this population. Population 2 includes ankerite crusts sampled along vadose passages, and has low $\delta^{13} \mathrm{C}$ $\left(-7.91\right.$ to $-7.87 \%$ ) and $\delta^{18} \mathrm{O}$ values $(-6.47$ to $-6.22 \%$ o), comparable with other carbonate speleothems precipitated from low-temperature meteoric solutions in other carbonate caves worldwide.

The oxygen isotopic composition of meteoric and sea water nearby the cave is $-5.6 \%$ o (Araguas- 


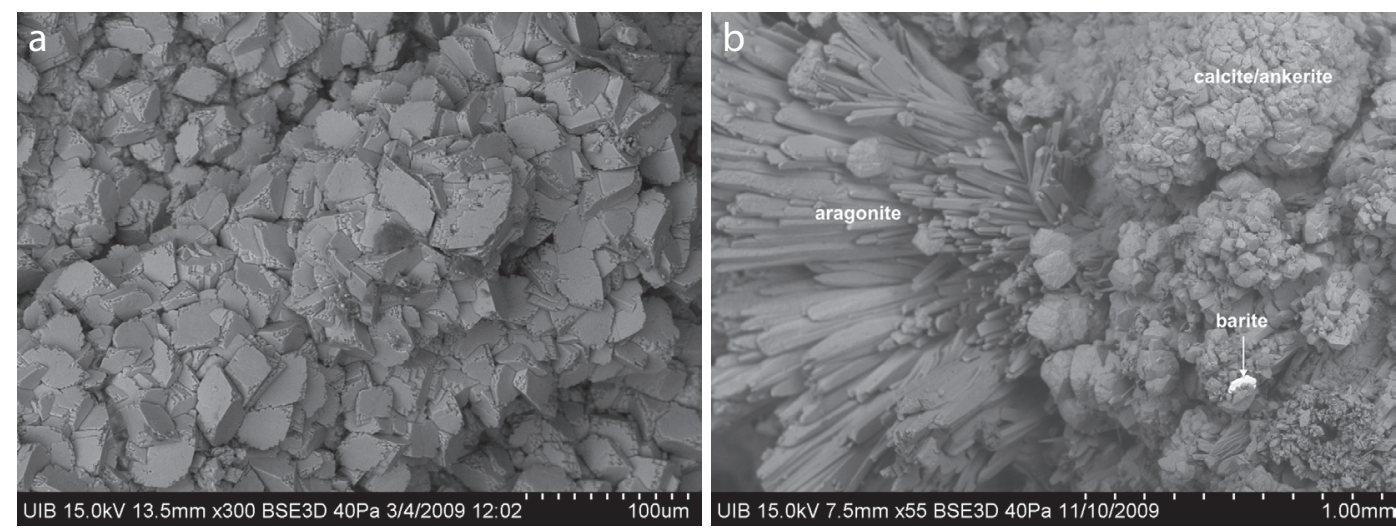

Fig. 9. BSE images of rhombohedral ankerite showing stepped morphology at edges and corners (a) and close up of needle-like aragonite and tabular barite crystals growing upon intimately associated calcite and ankerite (b).

that soil pool represents the main source of carbon. Furthermore, the observed distribution of $\delta^{18} \mathrm{O}$ values indicates that Population 1 apparently precipitated from brackish water of which isotopic signature is likely the result of mixed seawater and warm ascending waters. The more negative $\delta^{18} \mathrm{O}$ values of samples belonging to Population 2 plot close to the mean

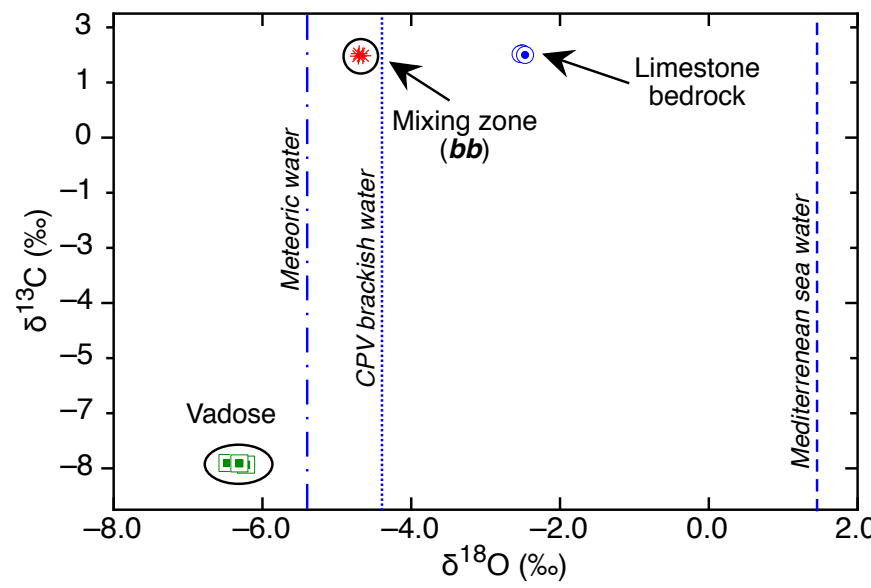

Fig. 10. Plot of carbon $\left(\delta^{13} \mathrm{C}\right)$ and oxygen $\left(\delta^{18} \mathrm{O}\right)$ isotopic composition of two cave ankerite populations and limestone bedrock. Data for modern meteoric (Araguas-Araguas \& Diaz Teijeiro, 2005), brackish, and Mediterranean sea waters (Boop et al., 2014) are also represented.

Araguas \& Diaz-Teijeiro, 2005) and $+1.5 \%$ (Boop et al., 2014), respectively. The average $\delta^{18} \mathrm{O}$ value of the limestone bedrock is $-3.5 \%$ whereas the $\delta^{13} \mathrm{C}$ value is $+2.0 \%$. Combining this information with our isotope data, it is reasonable to consider the ankerite within Population 1 as being deposited at the bedrock/brackish water interface. At these locations the reaction between the brackish water supplying $\mathrm{Mg}^{2+}$ and the carbonate bedrock is responsible for its precipitation. The iron is probably derived from ferric oxides deposited in limestones. This idea is supported by the fact that all three samples of Population 1 have almost similar $\delta^{13} \mathrm{C}$ values with the limestone, indicating that the source of carbon is likely the carbonate bedrock. Instead, the isotopic signature of samples in Population 2 clearly suggest

Table 2. Oxygen and carbon isotope values of bedrock limestone and ankerite speleothems from CPV.

\begin{tabular}{|l|c|c|}
\hline Location and Sample code & $\boldsymbol{\delta}^{18} \mathbf{O}(\%)$ & $\boldsymbol{\delta}^{13} \mathbf{C}(\%)$ \\
\hline Sector F (limestone) & -2.51 & 2.04 \\
\hline Sector Antic (limestone) & -2.53 & 2.02 \\
\hline Sector F (VL-M96) & -6.22 & -7.91 \\
\hline Sector F (VL-M101) & -6.47 & -7.87 \\
\hline Tragus Gallery (limestone) & -2.47 & 2.0 \\
\hline Tragus Gallery (VL-M26) & -6.31 & -7.88 \\
\hline Tragus Gallery (VL-M55) & -4.65 & 1.93 \\
\hline Tragus Gallery (VL-M57) & -4.7 & 1.98 \\
\hline Tragus Gallery (VL-M57a) & -4.71 & 1.97 \\
\hline
\end{tabular}

value of the meteoric water, thus suggesting these ankerite samples have a vadose origin and were deposited by percolating vadose solutions. It could be precipitated directly from low-temperature solutions or it may replace calcite, providing an adequate supply of $\mathrm{Fe}^{2+}$ and $\mathrm{Mg}^{2+}$ relative to $\mathrm{Ca}^{2+}$ is available. Ankerite is the product of the reaction between $\mathrm{Mg}^{2+}$ enriched meteoric solutions $\left(\mathrm{Mg}^{2+}\right.$ originates from sea spray or is leached from the carbonate bedrock) percolating through the epikarst and the Upper Miocene limestone.

\section{Epsomite}

The observations presented here are based on a single occurrence of epsomite, in sample VL-M030 recovered from the Tragus Gallery, more specifically, at the Aragonite Tub. The mineral occurs as a submillimeter thin, dull white to slightly yellowish fibrous crust closely associated with aragonite. Calcite was also identified in this sample by means of XRD. The precipitation and preservation of epsomite is highly dependent on temperature and relative humidity $(\mathrm{RH})$. Considering the stability field of epsomite provided by Hill \& Forti (1997) and Posern \& Kaps (2008) and the topoclimatic conditions within the Aragonite Tub ( $\mathrm{T}=20.4^{\circ} \mathrm{C}$ and $~ 90 \% \mathrm{RH}$ ), its occurrence in CPV is not surprising.

Our hypothesis regarding the presence of epsomite in CPV is as follows: according with Berner (1975), Fischbeck \& Müller (1971) and De Choudens-Sánchez \& González (2009), from a parent solution with Mg/Ca between 2.9 and 4.4, aragonite is the main calcium carbonate mineral (calcite may also form) that will precipitate. The only way to suppress aragonite deposition, but form epsomite, is to increase the molar ratios $\mathrm{SO}_{4}{ }^{2-} / \mathrm{CO}_{3}{ }^{2-}$ to $\geq 1$ while the solution remains rich in $\mathrm{Mg}^{2+}$. It has been experimentally documented that incorporation of less than $3 \mathrm{~mole} \%$ of sulfate is energetically unfavorable to aragonite precipitation (Fernández-Díaz et al., 2010).

The source of $\mathrm{Mg}^{2+}$ could have been the bedrock, percolating sea spray-rich waters, or even the close proximity of cave brackish water at a time when sealevel stood higher than present. Indistinguishable, the last two sources work for $\mathrm{SO}_{4}{ }^{2-}$ as well, knowing that the sulfur isotopic signature of the CPV epsomite $\left(\delta^{34} \mathrm{~S}=+21.3 \%\right.$; $\left.\mathrm{n}=3\right)$ points toward a marine source (Paytan et al., 1998). If epsomite precipitated during 
one of the high sea stands and both $\mathrm{Mg}^{2+}$ and $\mathrm{SO}_{4}{ }^{2-}$ come from the cave brackish water (evaporation of capillary pore waters), then it is with certainty that the mineral belongs to this genetic group.

\section{Minerals precipitated under vadose conditions}

This category includes the most common cave minerals; such are calcite, aragonite, gypsum, or huntite, precipitated throughout the cave ( $\mathrm{v}$ in Table 1) by flowing, dripping, seeping, or pooling water (Hill $\&$ Forti, 1997). These minerals are also present in the composition of speleothems in and around hypogene features (feeders, vents, cupolas) but at such locations they were deposited from cold meteoric waters in a late minerogenic stage. The precipitation of some minerals occurring in the highly weathered bedrock skin is likely controlled by microbial activity (bw $\pm(\mathrm{m})$ in Table 1$)$.

\section{Clay minerals}

Abundant colorful "corrosion" residues coat floors, walls, and ceilings in many parts of CPV (Figs. 3c and $11 \mathrm{a}, \mathrm{b})$. This "mineral skin" is several centimeters in thickness and its texture progressively changes from a very fluffy, low-density layer ( $\mathrm{mm}$ to $\mathrm{cm}$ thick) in the outer-most part to a soft, but denser one represented by weathered bedrock. Similar cave deposits were described in the literature under various names, such are okher (Maltsev, 1997) or speleosol (Spilde et al., 2006). Apparently, these materials are active biological media, rich in reworked and bacteriamediated secondary minerals (Korshunov \& Semikholennykh, 1994; Northup \& Lavoie, 2001; Polyak \& Provencio, 2001; Spilde et al., 2005; Barton $\&$ Northup, 2007). They are home of a variety of oxides and hydroxides of iron, manganese, and aluminum, as well as certain clay minerals. Apart from kaolinite, montmorillonite, and illite (Fig. 11c), the following mineral species were identified in the multicolored deposits of CPV: romanèchite, todorokite, goethite, hematite, gibbsite, and quartz.

To date, there are no dedicated studies to investigate the geomicrobiology and mineralogy of these residues in CPV. The clay minerals-rich "corrosion" residues

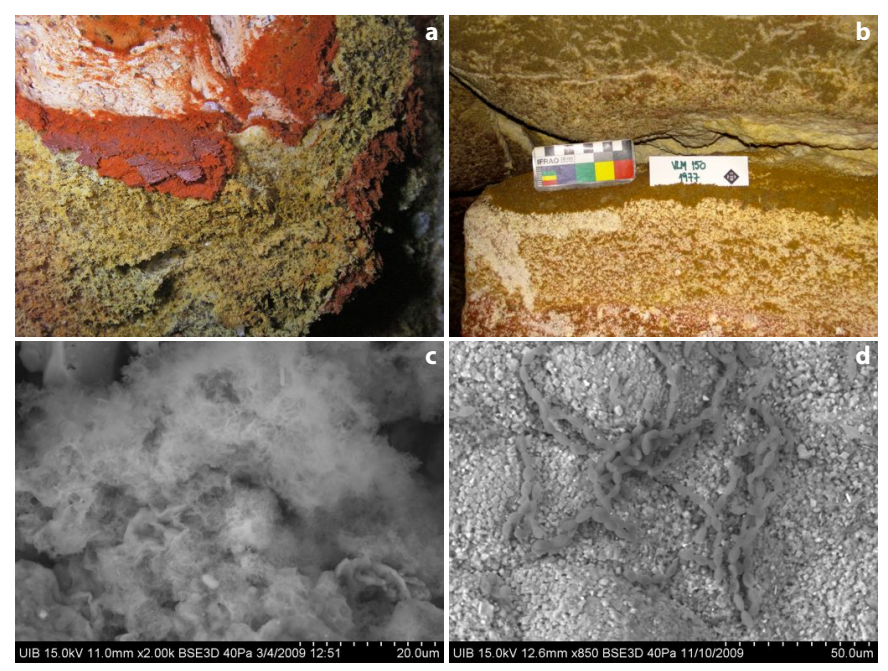

Fig. 11. a-b) Multicolored fluffy residue coating consisting of $\mathrm{Fe}$ and/or Mn oxides and hydroxides, clay minerals, calcite, and quartz silt; c) Feathery crystals of illite; d: SEM image reveals microbial structures within a sample of multicolored residual material. are very common nearby vents (26 out 33 samples total) where they form abundant accumulations on both ceilings and walls. Many other passages in the cave (more or less ventilated) display rich multicolored deposits. Regardless to their location within the cave, these weathering residues appear to be the result of a combination of condensation-corrosion that is significantly enhanced by biochemical breakdown of the bedrock. The idea that microorganisms are involved in this process is supported by SEM images that show bacterial filaments and other microbial structures (Fig. 11d).

\section{Dolomite}

Although a common rock in ancient sedimentary deposits, dolomite is relatively rare in the recent ones and even rarer as mineral in low temperature environments (Tucker, 2001). The reason for this situation is attributed to a number of factors including $\mathrm{Mg} / \mathrm{Ca}$ ratio, kinetics, temperature, $\mathrm{pH}$, presence of sulfates, etc. (see Roberts et al., 2013 and references therein). Only a handful of cave locations are known and well documented with respect to the presence of dolomite speleothems (Thrailkill, 1968; Martini, 1987; Hill \& Forti, 1997; Polyak \& Güven, 2000; AlonsoZarza \& Martín-Pérez, 2008).

Macroscopically, the dolomite in CPV occurs as white to gray sub-millimeter thin crusts precipitated on either side of rims around vents. Sometimes dolomite microcrystals are deposited upon aragonite crystals or gypsum coatings. In one sample (VL-M38) dolomite and huntite are closely associated. Typically, the dolomite occurs near hypogene features (18), but it was also found in 5 locations that are characterized by exuberant vadose precipitates.

A detailed morphological investigation by SEM reveals that commonly, dolomite forms isolated or coalescing spheroidal aggregates of various sizes (30 $\mu \mathrm{m}$ to $0.5 \mathrm{~mm}$ across; Fig. $12 \mathrm{a}, \mathrm{b})$, which internally consist of individual rhombic crystals (Fig. 12c). Notable are the bacterial filaments (Fig. 12d) and what appears to be mucus strands (Fig. 12e) that covers or bridges dolomite crystals in many of the investigated samples.

Considering the morphology of crystals and mineral assemblages with which dolomite is associated in CPV, the following precipitation scenarios are proposed:

1. Locations where dolomite occurs with aragonite and/or huntite. After calcite and aragonite were deposited out of dissolved inorganic carbon (DIC)-rich vadose solutions, these become enriched in $\mathrm{Mg}^{2+}$ and will precipitate huntite and then dolomite. Huntite and dolomite have similar structures, but huntite will always precipitate before dolomite because of its open structure (low-density phase; Graf \& Bradley, 1962; Dollase \& Reeder, 1986) that favors enhanced magnesium dehydration (Lippmann, 1973). Another possible way in which dolomite may have formed under this scenario is considering that either aragonite or huntite acted as precursors. An argument for such a process is the presence in some samples of micro-aggregates consisting 

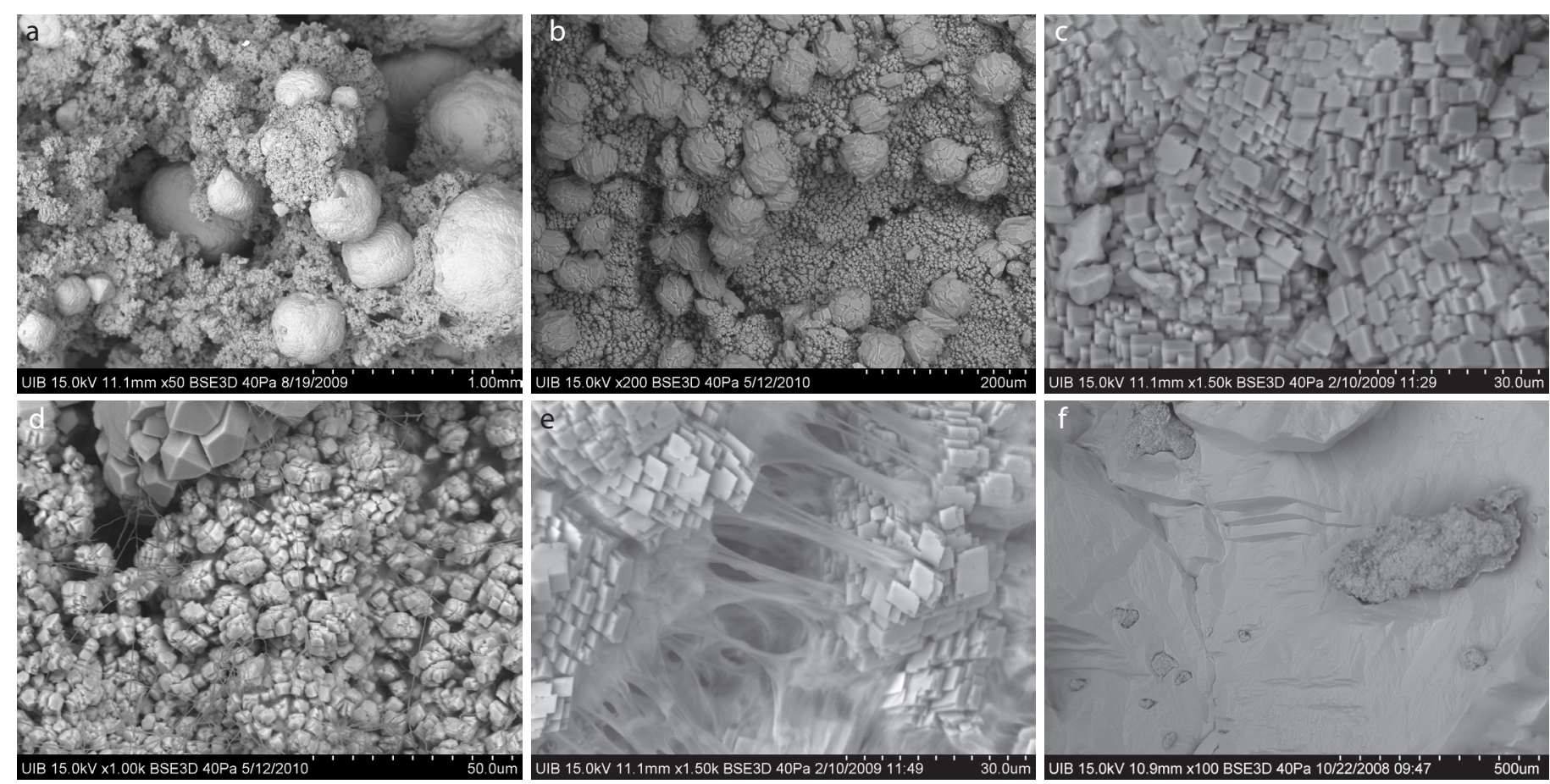

Fig. 12. a-b) Isolated and coalescing rounded aggregates of dolomite; c) Close up of dolomite crystals shaping the spheroidal aggregates; d-e) Bacterial and mucus strands bridging or covering dolomite crystals; f) Crystals of dolomite nested in corrosion pits at the surface of gypsum crystals.

of euhedral to subhedral dolomite crystals, tentatively interpreted as representing totally replaced huntite (Fig. 12a, b). A similar dolomite occurrence was described from Castañar Cave in Spain (Alonso-Zarza \& Martín-Pérez, 2008).

2. Locations where dolomite is associated with gypsum. A high-resolution SEM examination of sample VL-M22 shows dissolution pockets on the surface of gypsum that are filled with crystals of dolomite (Fig. 12f). Vadose fluids could simply cause corrosion of gypsum, but at the same time, it might be the result of microbial boring activity (Douglas \& Yang, 2002). Regardless the origin of the micro-dissolution features on the gypsum crystal faces, the dolomite filling them appears to be microbially mediated. This hypothesis is supported by SEM imagery that shows the presence of organic structures, binding or coating part of the dolomite crystals. Such examples are known from modern settings in Brazil and Spain (Vasconcelos et al., 1995; Sanz-Montero et al., 2006) as well as from laboratory experiments (Warthmann et al., 2000).

3. Locations where dolomite is only associated with calcite: The presence of the dolomite along with calcite in speleothems from CPV may suggest its precipitation from DIC-rich meteoric waters mixed with Mg-rich groundwaters. The source of magnesium could be twofold: 1) the extensive bodies of brackish water in CPV or/and 2) dissolution of magnesium from the bedrock.

Knowing that abiotic precipitation of modern dolomite is limited in low-temperature environments, and because the SEM observations on dolomite samples reveal biological structures, we argue, without any dedicated microbiological investigations that precipitation of dolomite in CPV is bio-induced.

\section{Huntite}

Eleven samples collected in the close proximity of vents in all three sectors of the cave tested positive for huntite. The mineral occurs as dull white, finegrained earthy deposits or moonmilk, as well as small spheres (Fig. 13a). SEM imaging reveals huntite is intimately associated with aragonite and dolomite (Fig. 13b, c). Inspecting at higher magnification the globular aggregates of huntite, we noticed that at their surface the platy rhomboidal crystals are visible (Fig. 13b inset).

Without exception, all huntite deposits occur near well-ventilated areas (in connection with the floor feeders), confirming its precipitation by evaporative concentration of magnesium-rich percolating solutions (mainly) and carbon dioxide loss. An interesting observation is that none of the common magnesium carbonates were identified in CPV. Because the precipitation of nesquehonite requires very high $\mathrm{CO}_{2}$ partial pressure $\left(\mathrm{P}_{\mathrm{CO} 2}\right)$ its absence is easy to explain (Lippmann, 1973). However, although the stability field of hydromagnesite overlaps the one of cave environment in terms of relative humidity, evaporation, and $\mathrm{P}_{\mathrm{CO} 2}$ (Hill \& Forti, 1997; White, 1997), the mineral is not forming in CPV. The reason might be twofold: the $\mathrm{P}_{\mathrm{CO} 2}$ is still too high or, more likely, the $\mathrm{Mg} / \mathrm{Ca}$ ratio is below the critical threshold (16) at which hydromagnesite forms (Fischbeck \& Müller, 1971).

On the theoretical curve of the evolution of cave water in the $\mathrm{CaCO}_{3}-\mathrm{MgCO}_{3}-\mathrm{H}_{2} \mathrm{O}$ system, huntite lies between aragonite and hydromagnesite. Thus, the presence of huntite and aragonite association at various locations within CPV confirms the depositional sequence of carbonate minerals proposed by Lippmann (1973). It also directly relates the two minerals with a late vadose speleogenesis phase. Diagenetic mechanisms similar to those invoked by Martinez-Pérez et al. (2012) 

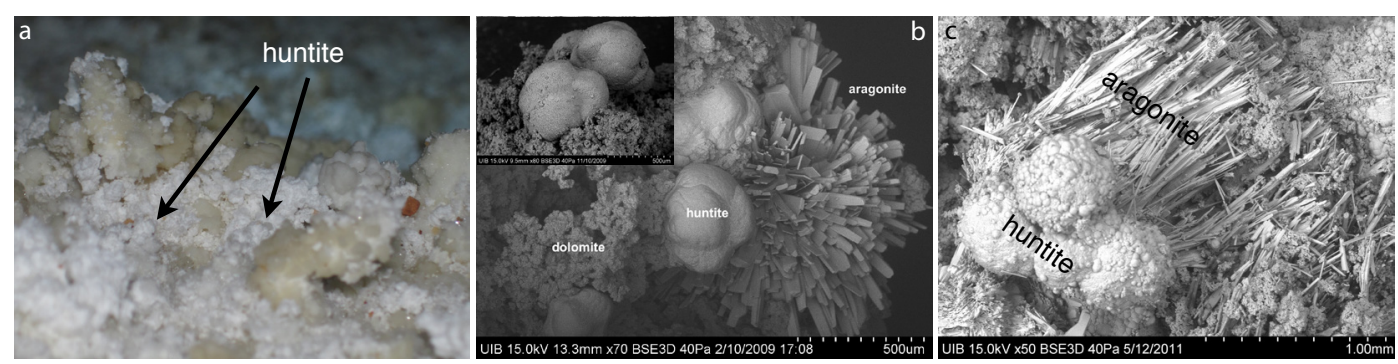

precipitation conditions for romanèchite. However, the literature dealing with cave ferromanganese deposits and their mineral constituents, considers the enrichment in $\mathrm{Mn}^{2+}$ and $\mathrm{Fe}^{2+}$ a result of microbial alteration of

Fig. 13. a) Moonmilk-type fine-grained aggregates of huntite precipitated over aragonite ( \pm dolomite) crusts in the close vicinity of vents; b) SEM microphotograph showing the association of huntite spheres (platy rhomboidal crystals are visible in the inset image) with prismatic aragonite crystals and micro-aggregates of dolomite; c) Close up SEM photo of spheres intergrown with acicular and prismatic aragonite crystals. the bedrock (Spilde et al., 2005, Spilde, 2006). Considering this scenario, the $\mathrm{Mn}^{3+}$ and $\mathrm{Mn}^{4+}$ in

in Castañar Cave (Spain) could be a viable alternative for huntite precipitation as well.

\section{Romanèchite}

Earlier known as psilomelan (now an obsolete term), romanèchite is a barium-containing manganese oxide, commonly occurring in caves in the composition of soft or hard dark brown to black ferromanganese coatings, crusts, nodules, and earthy deposits (Hill \& Forti, 1997; Onac et al., 1997; White et al., 2009; Gázquez et al., 2011). The sample analyzed (VL-M05) was collected near the end of the Galeria d'en Pau, where it occurs as black earthy masses. Apart from this location, ferromanganese deposits are widespread in CPV both in sediment sequences (Fornós et al., 2014) and as wall and ceiling deposits (Fornós et al., 2011).

Romanèchite crystals observed under SEM in our sample are either thin bladed or short acicular forming fibrous crusts (Fig. 14). The SEM imaging combined with mineral specific spot EDX analysis indicates that romanèchite is intergrown with hematite (also identified by means of XRD) and various clay minerals (Fig. 14, inset). This assemblage documents an intense subaerial weathering process, relating the presence of this mineral with a vadose phase in the cave evolution. Without further investigations it is difficult to precisely infer the

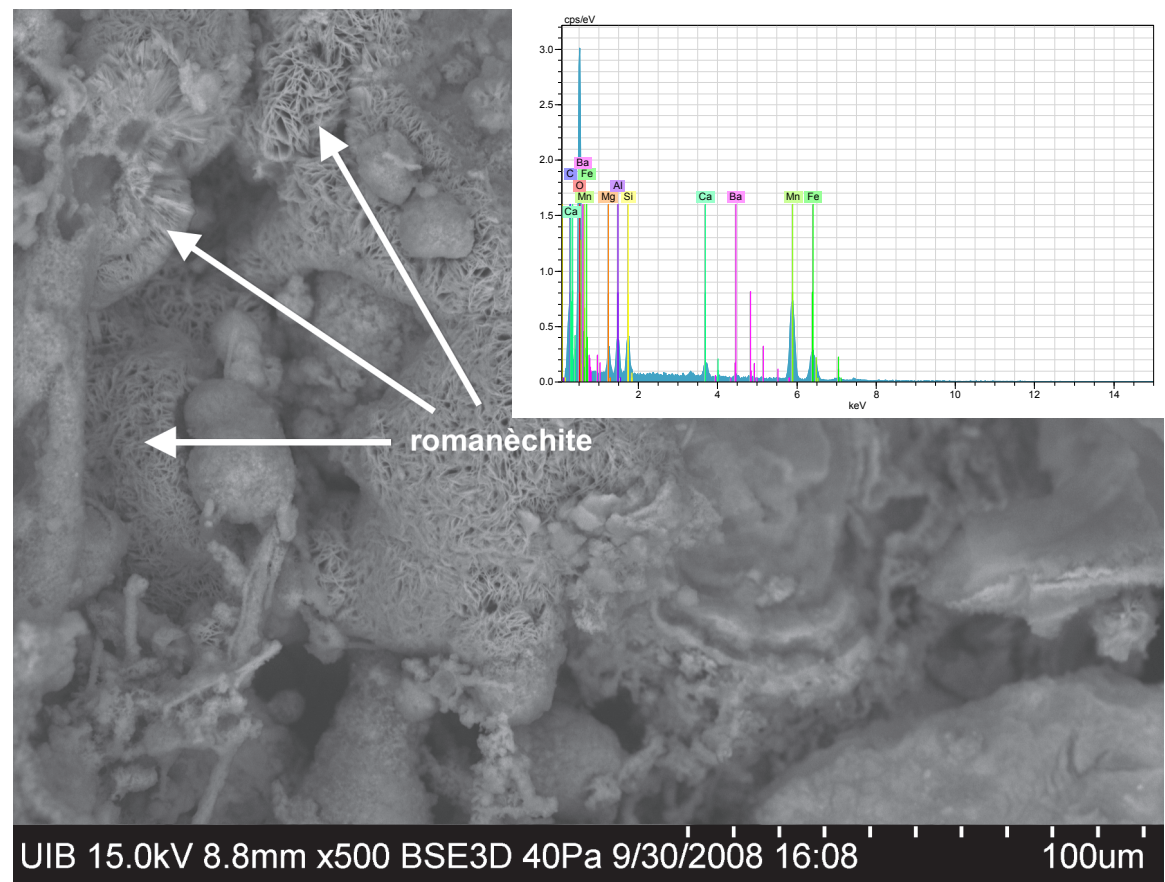

Fig. 14. Thin bladed and fibrous crusts of romanèchite. In inset, the EDS spectrum showing the presence of manganese and barium. the CPV romanèchite are probably a product of $\mathrm{Mn}^{2+}$ oxidation (a microbially mediated) in oxic, subaerial conditions. The barium is probably supplied by the carbonate bedrock in which concentrations of up to 1.5\% were found (Fornós et al., 2011).

\section{CONCLUSIONS AND IMPLICATIONS FOR SPELEOGENETIC DIAGNOSIS}

The excitement about investigating the minerals of Cova des Pas de Vallgornera came from the fact that the most diverse assemblages group around typical hypogene features occurring in Tragus and Nord sectors (21 species) as well as in Sector F (13). Only after detailed studies we learned that not all these minerals were precipitated in conjunction with a hypogenic phase. Considering the textural relationship between the minerals of a given assemblage, and noticing the absence of only hypogene or non-hypogene mineral associations, we concluded that their precipitation is a result of several mineral-forming events. Given the spatial distribution of cave minerals throughout CPV, we argue that particular mineral associations are also related to different speleogenetic phases (seacoast mixing, ascending thermal groundwater, and meteoric recharge) in the cave evolution.

The minerogenic role of ascending thermal waters in the Mallorcan karst is somehow different from the classical one documented in caves under Budapest (Hungary). At certain locations the hot waters rising from depth are responsible for the precipitation of an abundant and diverse suite of carbonates and sulfates (gypsum, barite, and celestine), along with some exotic minerals (e.g., fluorite, quartz, etc.; Dublyansky, 1995; LeélÖssy et al., 2011). In contrast, in CPV the minerals are not deposited directly from deep-seated thermal groundwaters, but instead, they are a product of the interaction between mineralized warm brackish waters and the carbonate bedrock or preexisting minerals. Thus, most minerals (e.g., aragonite, barite, celestine, jacobsite, todorokite, etc.) were precipitated inside feeders while the solutions moved upward and in the near vicinity of vents (floor, wall, or ceiling). 
In addition, the rising hot air released by these waters is responsible for complex replacement and condensationcorrosion processes acting upon bedrock. The result is a fluffy colorful organo-mineral thick skin, rich in clay minerals, $\mathrm{Fe}$ and/or Mn oxides and hydroxides (goethite, hematite, romanèchite, todorokite), chamosite, and quartz silt. Traces of microbial activity observed under SEM suggest microorganisms may play a significant role in the precipitation of certain minerals in CPV.

Ankerite, aragonite, calcite, dolomite, epsomite, and gypsum are the only minerals in the composition of speleothems occurring nearby (above, at, and below) the brackish water table. Apart from sea-controlled calcite and aragonite phreatic overgrowths on speleothems (POS), which are widespread in CPV, all the other minerals occur as crusts, coatings, and minute crystals. All are precipitated from cold, $\mathrm{Ca}^{2+}, \mathrm{Mg}^{2+}$, and $\mathrm{SO}_{4}{ }^{2-}$-rich brackish waters.

The mineralogy of speleothems deposited from lowtemperature, downward-circulating meteoric waters is dominated by calcite. Gypsum, aragonite, dolomite, and ankerite are the other important mineral species associated with a late-stage, vadose cave evolution. Some less frequent minerals were also identified in the composition of other vadose speleothems (Table 1).

Although barite, celestine, todorokite, gibbsite, and nordstrandite were earlier associated with sulfuric acid speleogenesis (Polyak \& Provencio, 2001; Onac et al., 2009), none of these or any of the other investigated cave minerals in CPV are actually speleogenetic by-products. This observation is supported by our stable isotope $\left(\delta^{13} \mathrm{C}\right.$, $\mathrm{\delta}^{18} \mathrm{O}$, and $\mathrm{\delta}^{34} \mathrm{~S}$ ) investigations.

Here we show that combining mineralogical mapping throughout CPV with precise mineral phase identification and textural relationship analysis is an efficient way to understand various mineral-forming events and their link to particular speleogenetic pathways. In this vein, stable isotope studies provide strong evidences that further help deciphering both the mineral origin and cave genetic history.

\section{ACKNOWLEDGEMENTS}

Part of this study is based upon work supported by the National Science Foundation under grant AGS-1103108 to BPO, the CGL2010-18616 project from the Spanish Government to JJF. We express our gratitude to Drs. J. Cifre and F. Hierro (Serveis Científico-Tècnics, Universitat de Illes Balears, Palma), Conselleria de Medi Ambient who granted permission to sample the cave and to T. Mulet, G. Mulet, A. Kristofersson, and T. Croix who helped with cave logistics and sample collection. The authors are indebted to Drs. F. Frau, F. Gázquez, and G. Lazaridis for their pertinent suggestions.

\section{REFERENCES}

Akande S.O. \& Mücke A., 1993 - Depositional environment and diagenesis of carbonates at the Mamu/Nkporo Formation, Anambra Basin, Southern Nigeria. Journal of African Earth Sciences, 17 (4): 445-456.

http://dx.doi.org/10.1016/0899-5362(93)90003-9
Alonso-Zarza A.M. \& Martín-Pérez A., 2008 - Dolomite in caves: Recent dolomite formation in oxic, non-sulfate environments. Castañar Cave, Spain. Sedimentary Geology, 205: 160-164.

http://dx.doi.org/10.1016/j.sedgeo.2008.02.006

Araguas-Araguas L.J. \& Diaz-Teijeiro M.F., 2005 - Isotope composition of precipitation and water vapour in the Iberian Peninsula: first results of the Spanish Network of Isotopes in Precipitation. In: International Atomic Energy Agency Isotopic composition of precipitation in the Mediterranean Basin in relation to air circulation patterns and climate. International Atomic Energy Agency, 173-190.

Audra P., Gázquez F., Rull F., Bigot J.-Y. \& Camus H., 2013 - Hypogene sulfuric acid speleogenesis and rare sulfate minerals (fibroferrite, jarosite, jarosite subgroup) Baume Galiniere Cave (Alpes-de-Haute-Provence, France). In: Filippi M. \& Bosák P. (Eds.), Proceedings of the $16^{\text {th }}$ International Congress of Speleology. Praha: Czech Speleological Society, 3: 449-453.

Barton H.A. \& Northup D.E., 2007 - Geomicrobiology in cave environments: past, current and future perspectives. Journal of Cave and Karst Studies, 69 (1): 163-178.

Berner R.A., 1975 - The role of magnesium in the crystal growth of calcite and aragonite from sea water. Geochimica et Cosmochimica Acta, 39 (4): 489-494. http://dx.doi.org/10.1016/0016-7037(75)90102-7

Bonny S. \& Jones B., 2003 - Relict tufa at Miette Hot Springs, Jasper National Park, Alberta, Canada. Canadian Journal of Earth Sciences, 40: 1459-1481. http://dx.doi.org/10.1139/e03-050

Boop L.M., Onac B.P., Wynn J.G., Fornós J.J., Rodríguez-Homar M. \& Merino A., 2014 - Groundwater geochemistry observations in littoral caves of Mallorca (western Mediterranean): implications for deposition of phreatic overgrowths on speleothems. International Journal of Speleology, 43 (2): 193-203. http://dx.doi.org/10.5038/1827-806X.43.2.7

Bottrell S.H., Smart P.L., Whitaker F. \& Raiswell R., 1991 - Geochemistry and isotope systematics of sulphur in the mixing zone of Bahamian blue holes. Applied Geochemistry, 6: 97-103.

http://dx.doi.org/10.1016/0883-2927(91)90066-X

Busenberg E., Plummer L.N. \& Parker V.B., 1984 - The solubility of strontianite $\left(\mathrm{SrCO}_{3}\right)$ in $\mathrm{CO}_{2}-\mathrm{H}_{2} \mathrm{O}$ solutions between 2 and $91^{\circ} \mathrm{C}$, the association constants of $\mathrm{SrHCO}_{3}{ }^{+}$(aq) and $\mathrm{SrCO}_{3}{ }^{\circ}$ (aq) between 5 and $80^{\circ} \mathrm{C}$, and an evaluation of the thermodynamic properties of $\mathrm{Sr}^{2+}$ (aq) and $\mathrm{SrCO}_{3}$ (cr) at $25^{\circ} \mathrm{C}$ and $1 \mathrm{~atm}$ total pressure. Geochimica et Cosmochimica Acta, 48 (10): 2021-2035. http://dx.doi.org/10.1016/0016-7037(84)90383-1

Calaforra J.M., De Waele J., Forti P., Galli E. \& Ebadi M., 2013 - Strontianite from Serizjan Cave (Iran): a new occurrence of this rare cave mineral with discussion on its genesis. In: Filippi M. \& Bosák P. (Eds.), Proceedings of the $16^{\text {th }}$ International Congress of Speleology. Praha: Czech Speleological Society, 3: 449-453.

Csoma A.E., Goldstein R.H. \& Pomar, L., 2006 Pleistocene speleothems of Mallorca: implications for palaeoclimate and carbonate diagenesis in mixing zones. Sedimentology, 53: 213-236. http://dx.doi.org/10.1111/j.1365-3091.2005.00759.x

De Choudens-Sánchez V. \& González L.A., 2009 Calcite and aragonite precipitation under controlled instantaneous supersaturation: elucidating the role of $\mathrm{CaCO}_{3}$ saturation state and $\mathrm{Mg} / \mathrm{Ca}$ ratio on calcium carbonate polymorphism. Journal of Sedimentary Research, 79: 363-376.

http://dx.doi.org/10.2110/jsr.2009.043 
Dollase W.A. \& Reeder R.J., 1986 - Crystal structure refinement of huntite, $\mathrm{CaMg}_{3}\left(\mathrm{CO}_{3}\right)_{4}$, with X-ray powder data. American Mineralogist, 71 (1-2): 163-166.

Dorale J.A., Onac B.P., Fornós J.J., Ginés J., Ginés A., Tuccimei P. \& Peate D.W., 2010 - Sea-level highstand 81,000 years ago in Mallorca. Science, 327: 860-863. http://dx.doi.org/10.1126/science.1181725

Douglas S. \& Yang H., 2002 - Mineral biosignatures in evaporites: presence of rosickite in an endoevaporitic microbial community from Death Valley, California. Geology, 30: 1075-1078.

http://dx.doi.org/10.1130/0091-7613(2002)030<1075: MBIEPO $>2.0 . \mathrm{CO} ; 2$

Dublyansky Y.V., 1995 - Speleogenetic history of the Hungarian hydrothermal karst. Environmental Geology, 25: 24-35. http://dx.doi.org/10.1007/BF01061827

Dublyansky Y.V., 1997 - Hydrothermal cave minerals. In: Hill C.A. \& Forti P. (Eds.), Cave minerals of the world $\left(2^{\text {nd }}\right.$ ed.). Huntsville: National Speleological Society: 252-255.

Dublyansky Y.V., 2000 - Hydrothermal speleogenesis: its settings and peculiar features. In: Klimchouk A., Palmer A.N., Ford D.C. \& Dreybrodt W. (Eds.), Speleogenesis: Evolution of karst aquifers. Huntsville: National Speleological Society: 292-297.

Dublyansky Y.V., 2012 - Hydrothermal caves. In: White W.B. \& Culver D.C. (Eds.), Encyclopedia of caves (2 ${ }^{\text {nd }}$ ed.). Amsterdam: Academic Press: 391-397. http://dx.doi.org/10.1016/B978-0-12-383832-2.00055-4

Fernández-Díaz L., Fernández-González Á. \& Prieto M., 2010 - The role of sulfate groups in controlling $\mathrm{CaCO}_{3}$ polymorphism. Geochimica et Cosmochimica Acta, 74: 6064-6076.

http://dx.doi.org/10.1016/j.gca.2010.08.010

Fernández-Rubio R., Eraso A., Ortega M., Arana R. \& Rojas E., 1975 - Estudio de la Sima termal de las Fumarolas (Montevives, Granada, España). Annales de Spéléologie, 30 (2): 287-302.

Fischbeck R. \& Müller G., 1971 - Monohydrocalcite, hydromagnesite, nesquehonite, dolomite, aragonite, and calcite in speleothems of the Fränkische Schweiz, Western Germany. Contributions to Mineralogy and Petrology, 33: 87-92. http:/ /dx.doi.org/10.1007/BF00386107

Ford D.C. \& Williams P., 2007 - Karst hydrogeology and geomorphology. John Wiley \& Sons, West Sussex, 562 p. http://dx.doi.org/10.1002/9781118684986

Fornós J.J. \& Gelabert B., 1995 - Lithology and tectonics of the Majorcan karst. Endins, 20, Monografies de la Societat d'Història Natural de les Balears 3: 27-43.

Fornós J.J., Merino A., Ginés J., Ginés A. \& Gràcia F., 2011 - Solutional features and cave deposits related to hypogene speleogenetic processes in a littoral cave of Mallorca Island (western Mediterranean). Carbonates and Evaporites, 26 (1): 69-81.

Fornós J.J., Ginés J., Gràcia F., Merino A., Gómez-Pujol L. \& Bover P., 2014 - Cave deposits and sedimentary processes in Cova des Pas de Vallgornera (Mallorca, Western Mediterranean). International Journal of Speleology, 43 (2): 159-174.

http://dx.doi.org/10.5038/1827-806X.43.2.5

Gázquez F., Calaforra J. \& Forti P., 2011 - Black Mn-Fe crusts as palaeoenvironmental markers. International Journal of Speleology, 40 (2): 163-169

http://dx.doi.org/10.5038/1827-806X.40.2.8

Ginés A. \& Ginés J., 2007 - Eogenetic karst, glacioeustatic cave pools and anchialine environments on Mallorca Island: a discussion of coastal speleogenesis. International Journal of Speleology, 36 (2): 57-67. http://dx.doi.org/10.5038/1827-806X.36.2.1
Ginés A., Ginés F. \& Gràcia, F., 2013 - Cave development and patterns of caves and cave systems in the eogenetic coastal karst of southern Mallorca (Balearic Islands, Spain). In: Lace M.J. \& Mylroie J.E (Eds.), Coastal karst landforms, Coastal Research Library, 5: 245-260.

Ginés J., Fornós J.J., Ginés A., Merino A. \& Gràcia F., 2014 - Geologic constraints and speleogenesis of Cova des Pas de Vallgornera, a complex coastal cave from Mallorca Island (Western Mediterranean). International Journal of Speleology, 43 (2): 105-124 http://dx.doi.org/10.5038/1827-806X.43.2.2

Ginés J., Ginés A., Fornós J.J., Merino A. \& Gràcia F., 2009 - On the role of hypogene speleogenesis in shaping the coastal endokarst of southern Mallorca (Western Mediterranean). In: Klimchouk A.B. \& Ford D.C. (Eds.), Hypogene speleogenesis and karst hydrogeology of artesian basins. Ukrainian Institute of Speleology and Karstology, Simferopol, Special Paper 1: 91-99.

Ginés J., Ginés A., Fornós J.J., Tuccimei P., Onac B.P. \& Gràcia F., 2012 - Phreatic overgrowths on speleothems (POS) from Mallorca, Spain: updating forty years of research. In: Ginés A., Ginés J., Gómez-Pujol L., Onac B.P. \& Fornós J.J. (Eds.), Mallorca: a Mediterranean benchmark for Quaternary studies. Palma de Mallorca: Monografies de la Societat d'Història Natural de les Balears, 18: 111-146.

Graf D.L. \& Bradley W.F., 1962 - The crystal structure of huntite, $\mathrm{Mg}_{3} \mathrm{Ca}\left(\mathrm{CO}_{3}\right)_{4}$. Acta Crystallographica, 5: 238-242. http://dx.doi.org/10.1107/S0365110X62000584

Grassineau N., Mattey D. \& Lowry D., 2001 - Sulfur isotope analysis of sulfide and sulfate minerals by continuous low-isotope ratio mass spectrometry. Analytical Chemistry, 73: 220-225. http://dx.doi.org/10.1021/ac000550f

Hathaway J.C. \& Schlanger S.O., 1962 - Nordstrandite from Guam. Nature, 196: 265-266. http://dx.doi.org/10.1038/196265a0

Helz G.R. \& Holland H.D., 1965 - The solubility and geologic occurrence of strontianite. Geochimica et Cosmochimica Acta, 29 (12): 1303-1315.

http://dx.doi.org/10.1016/0016-7037(65)90008-6

Herman J.S., Back W. \& Pomar L., 1985 - Geochemistry of groundwater in the mixing zone along the east coast of Mallorca, Spain. Proceedings of the Ankara-Antalya Symposium, Karst Water Resources, IAHS Publication, 161: 467-479.

Hill C.A., 1981 - Speleogenesis of Carlsbad Caverns and other caves of the Guadalupe Mountains. In: Proceedings of the $8^{\text {th }}$ International Congress of Speleology. Bowling Green: National Speleological Society: 143-144.

Hill C.A., 1987 - Geology of Carlsbad Cavern and other caves in the Guadalupe Mountains, New Mexico and Texas. New Mexico Bureau of Mines and Mineral Resources Bulletin, 117: 150 p.

Hill C.A. \& Forti P., 1997 - Cave minerals of the world $\left(2^{\text {nd }}\right.$ ed.). Huntsville: National Speleological Society, 464 p.

Hubbard C.R. \& Snyder R.L, 1998 - RIR-measurement and use in quantitative $X R D$. Powder Diffraction, 3 (2): 74-77. http://dx.doi.org/10.1017/S0885715600013257

Kirkland D.W., 1982 - Origin of gypsum deposits in Carlsbad Caverns, New Mexico. New Mexico Geology, 4: 20-21.

Klimchouk A., 2009 - Morphogenesis of hypogenic caves. Geomorphology, 106: 100-117.

http://dx.doi.org/10.1016/j.geomorph.2008.09.013

Korshunov V. \& Semikholennykh A., 1994 - A model of speleogenetic processes connected with bacterial redox in sulfur cycles in the caves of Kugitangtou Ridge, Turkmenia. In: Sasowsky I.D. \& Palmer M.V. (Eds.), Breakthroughs in karst geomicrobiology and redox geochemistry (abstract and field-trip guide). Colorado Springs: Karst Waters Institute: 43-44. 
Leél-Őssy S., Szanyi G. \& Surányi G., 2011 - Minerals and speleothems of the József-hegy Cave (Budapest, Hungary). International Journal of Speleology, 40 (2): 191-203. http://dx.doi.org/10.5038/1827-806X.40.2.11

Lipin V.A., 2001 - A new technique for synthesis of nordstrandite. Russian Journal of Applied Chemistry, 74 (2): 184-187.

http://dx.doi.org/10.1023/A:1012749428765

Lippmann F., 1973 - Sedimentary carbonate minerals. Springer Verlag, Berlin, 229 p. http://dx.doi.org/10.1007/978-3-642-65474-9

López J.M., 2008 - Yacimientos y potencial geotérmico del Archipielago Balear. Proceedings of the I Congreso de energía geotérmica en la edificación y la industria Geoener, Madrid, 21-30.

Maltsev V., 1997 - Cupp-Coutunn Cave, Turkmenistan. In: Hill C.A. \& Forti P. (Eds.), Cave minerals of the world $\left(2^{\text {nd }}\right.$ ed.). Huntsville: National Speleological Society: 323-328

Martínez-Pérez A., Martín-García, R. \& Alonso-Zarza, A.M., 2012 - Diagenesis of a drapery speleothem from Castañar Cave: from dissolution to dolomitization. International Journal of Speleology, 41: 251-266. http://dx.doi.org/10.5038/1827-806X.41.2.11

Martini J.E.J., 1987 - Les phenomenes karstiques des Quartzites d'Afrique du Sud. Karstologia, 9: 45-52.

Mateos R.M., López J.M. \& Sánchez-Guzmán J., 2005 Most recent explorations projects in Spain. Geothermal research of the Llucmajor area, Mallorca (Balearic Islands). IGA News, 62: 4-7.

Merino A., Fornós J.J. \& Onac B.P., 2009 - Preliminary data on mineralogical aspects of cave rims and vents in Cova des Pas de Vallgornera, Mallorca. In: White W.B. (Ed.), Proceedings of the $15^{\text {th }}$ International Congress of Speleology. Kerrville: National Speleological Society, 1: 307-311.

Merino A., Ginés J., Tuccimei P., Soligo M. \& Fornós J.J., 2014b - Speleothems in Cova des Pas de Vallgornera. Their distribution and characteristics within an extensive coastal cave from the eogenetic karst of southern Mallorca (Western Mediterranean). International Journal of Speleology, 43 (2): 125-142. http: / /dx.doi.org/ 10.5038/1827-806X.43.2.3

Merino A., Mulet A., Mulet G., Croix A., Kristofersson A., Gràcia F. \& Perelló M.A., 2014a - Cova des Pas de Vallgornera (Mallorca, Spain): History of exploration and cave description. International Journal of Speleology, 43 (2): 95-104.

http://dx.doi.org/10.5038/1827-806X.43.2.1

Merino A., Mulet A., Mulet G., Croix A., Kristofersson A., Gràcia F., Ginés J., \& Fornós J.J., 2011b - La Cova des Pas de Vallgornera (Llucmajor, Mallorca). La cavitat de major desenvolupament de les Illes Balears. In: Gràcia F., Ginés J., Pons G.X., Ginard A. \& Vicens D. (Eds.), El carst: patrimoni natural de les Illes Balears. Endins, 35 / Monografies de la Societat d'Història Natural de les Balears, 17: 147-164.

Milton C., 1975 - Nordstrandite, $\mathrm{Al}(\mathrm{OH})_{3}$, from the Green River Formation in Rio Blanco County, Colorado. American Mineralogist, 60: 285-291.

Mylroie J.E., 2013 - Coastal karst development in carbonate rocks. In: Lace M.J. \& Mylroie J.E (Eds.), Coastal karst landforms, Coastal Research Library, 5: $77-109$.

Mylroie J.E. \& Carew J.L., 1990 - The flank margin model for dissolution cave development in carbonate platforms. Earth Surface Processes and Landforms, 15: 413-424. http://dx.doi.org/10.1002/esp.3290150505
Northup D.E. \& Lavoie K.H., 2001 - Geomicrobiology of caves: a review. Geomicrobiology Journal, 18: 199-222. http://dx.doi.org/10.1080/01490450152467750

Onac B.P. \& Forti, P., 2011 a - Minerogenetic mechanisms occurring in the cave environment: an overview. International Journal of Speleology, 40: 79-98. http://dx.doi.org/10.5038/1827-806X.40.2.1

Onac B.P. \& Forti, P., 2011b - State of the art and challenges in cave minerals studies. Studia UBB Geologia, 56: 33-42. http://dx.doi.org/10.5038/1937-8602.56.1.4

Onac B.P., Hess J.W. \& White W.B., 2007 - The relationship between the mineral composition of speleothems and mineralization of breccia evidence from Corkscrew Cave, Arizona. Canadian Mineralogist, 45: 1177-1188. http://dx.doi.org/10.2113/gscanmin.45.5.1177

Onac B.P., Mylroie J.E. \& White W.B., 2001 - Mineralogy of cave deposits on San Salvador Bahamas. Carbonates and Evaporites, 16 (1): 8-16. http://dx.doi.org/10.1007/BF03176222

Onac B.P., Pedersen R.B. \& Tysseland M., 1997 - Presence of rare-earth elements in black ferromanganese coatings from Vântului Cave (Romania). Journal of Caves and Karst Studies, 59 (3): 128-131.

Onac B.P., Wynn J.G. \& Sumrall J.B., 2011 - Tracing the sources of cave sulfates: a unique case from Cerna Valley, Romania. Chemical Geology, 288: 105-114. http://dx.doi.org/10.1016/j.chemgeo.2011.07.006

Onac B.P., Effenberger H.S. Wynn, J.G. \& Povară I., 2013 - Rapidcreekite in the sulfuric acid weathering environment of Diana Cave, Romania. American Mineralogist, 98: 1302-1309. http://dx.doi.org/10.2138/am.2013.4452

Onac B.P., Fornós J.J., Ginés A. \& Ginés J., 2005 Mineralogical reconnaissance of caves from Mallorca Island. Endins, 27: 131-140.

Onac B.P., Sumrall J., Mylroie J.E. \& Kearns J., 2008 Cave minerals of San Salvador Island, Bahamas. The University of South Florida Karst Studies Series, 1, 70 p. Onac B.P., Sumrall J.B., Tămaş T., Povară I., Kearns J., Dârmiceanu V., Vereş D. \& Lascu C., 2009 - The relationship between cave minerals and $\mathrm{H}_{2} \mathrm{~S}$-rich thermal waters along the Cerna Valley (SW Romania). Acta Carsologica, 38: 67-79.

Palmer A.N., 2007 - Cave Geology. Cave Books, Dayton, 454 p. Palmer A.N., 2011 - Distinction between epigenic and hypogenic maze caves. Geomorphology, 134: 9-22. http://dx.doi.org/10.1016/j.geomorph.2011.03.014

Palmer M.V. \& Palmer A.N., 2012 - Petrographic and isotopic evidence for late-stage processes in sulfuric acid caves of the Guadalupe Mountains, New Mexico, USA. International Journal of Speleology, 41 (2): 231 250. http://dx.doi.org/10.5038/1827-806X.41.2.10

Paytan A., Kastner M., Campbell D. \& Thinness M.H., 1998 - Sulfur isotopic composition of Cenozoic seawater sulfate. Science, 282: 1459-1462.

http://dx.doi.org/10.1126/science.282.5393.1459

Plan L., Tschegg C., De Waele J. \& Spötl C., 2012 Corrosion morphology and cave wall alteration in an Alpine sulfuric acid cave (Kraushöhle, Austria). Geomorphology, 169-170: 45-54.

http://dx.doi.org/10.1016/j.geomorph.2012.04.006

Polyak V.J. \& Güven N., 2000 - Clays in caves of the Guadalupe Mountains, New Mexico. Journal of Cave and Karst Studies, 62 (2): 120-126.

Polyak V.J. \& Provencio P., 2001 - By-product materials related to $\mathrm{H}_{2} \mathrm{~S}-\mathrm{H}_{2} \mathrm{SO}_{4}$ influenced speleogenesis of Carlsbad, Lechuguilla, and other caves of the Guadalupe Mountains, New Mexico. Journal of Cave and Karst Studies, 63: 23-32. 
Posern K. \& Kaps C., 2008 - Humidity controlled calorimetric investigation of the hydration of $\mathrm{MgSO}_{4}$ hydrates. Journal of Thermal Analysis and Calorimetry, 92 (3): 905-909. http://dx.doi.org/10.1007/s10973-007-8640-4

Puşcaş C.M., Onac B.P., Effenberger H.S. \& Povară I., 2013 - Tamarugite-bearing paragenesis formed by sulphate acid alteration in Diana Cave, Romania. European Journal of Mineralogy, 25: 479-486.

Rieder M., Cavazzini G., D'yakonlov Y.S., FrankKamenetskii V.A., Gattardi G., Guggenheim S., Koval P.V., Müller G., Neiva A.M.R., Radoslovich E.W., Robert J.-L., Sassi F.P., Takeda H., Weiss Z. \& Wones D.R., 1998 - Nomenclatures of the micas. Clays and Clay Minerals, 46 (5): 586-595.

http://dx.doi.org/10.1346/CCMN.1998.0460513

Roberts J.A., Kenward P.A., Fowle D.A., Goldstein R.H., González L.A. \& Moore D.S., 2013 - Surface chemistry allows for abiotic precipitation of dolomite at low temperature. Proceedings of the National Academy of Sciences, 110 (36): 14540-14545. http://dx.doi.org/10.1073/pnas.1305403110

Sanz-Montero M.E., Rodríguez-Aranda J.P. \& Calvo J.P., 2006 - Mediation of endoevaporitic microbial communities in early replacement of gypsum by dolomite. A case from Miocene lake deposits of the Madrid Basin, Spain. Journal of Sedimentary Research, 76: 12571266. http://dx.doi.org/10.2110/jsr.2006.122

Sauro F., Tisato N., De Waele J., Bernasconi S.M., Bontognali T.R.R. \& Galli E., 2014a - Source and genesis of sulphate and phosphate-sulphate minerals in quartz-sandstone cave environment. Sedimentology. http://dx.doi.org/10.1111/sed.12103

Sauro F., De Waele J., Onac B.P., Galli E., Dublyansky Y., Baldoni E. \& Sanna L., 2014b - Hypogenic speleogenesis in quartzite: the case of Corona 'e Sa Craba Cave (SW Sardinia, Italy). Geomorphology, 211: 77-88.

http://dx.doi.org/10.1016/j.geomorph.2013.12.031

Spilde M.N., Northup D.E., Boston P.J., Schelble R.T., Dano K.E., Crossey L.J. \& Dahm C.N., 2005 - Geomicrobiology of cave ferromanganese deposits: A field and laboratory investigation. Geomicrobiology Journal, 22: 99-116. http://dx.doi.org/10.1080/01490450590945889

Spilde M.N., Northup D.E. \& Boston P.J., 2006 Ferromanganese deposits in the caves of the Guadalupe Mountains. Caves and Karst of Southeastern New Mexico. New Mexico Geological Society $57^{\text {th }}$ Fall Field Conference Guidebook, 161-166.

Takácsné Bolner K., 1989 - Regional and special genetic marks on the Pál-völgy cave, the largest cave of thermal water origin in Hungary. Proceedings $10^{\text {th }}$ International Congress of Speleology, Budapest, 819-822.

Temovski M., Audra P., Mihevc A., Spangenberg J., Polyak V., McIntosh W. \& Bigot J., 2013 - Hypogenic origin of Provalata Cave, Republic of Macedonia: a distinct case of successive thermal carbonic and sulfuric acid speleogenesis. International Journal of Speleology, 42 (3): 235-246. http://dx.doi.org/10.5038/1827-806X.42.3.7
Thrailkill J., 1968 - Dolomite cave deposits from Carlsbad Caverns. Journal of Sedimentary Research, 38 (1): 141-145.

Tuccimei P., Soligo M., Ginés J., Ginés A., Fornós J.J., Kramers J. \& Villa I.M., 2010 - Constraining Holocene sea levels using U-Th ages of phreatic overgrowths on speleothems from coastal caves in Mallorca (Western Mediterranean). Earth Surface Processes and Landforms, 35 (7): 782-790.

Tucker M.E., 2001 - Sedimentary Petrology: an introduction to the origin of sedimentary rocks ( $3^{\text {rd }}$ ed.). Oxford, Blackwell Science, 262 p.

Van Everdingen R.O., Shakur M.A. \& Krouse H.R., 1985 - Role of corrosion by $\mathrm{H}_{2} \mathrm{SO}_{4}$ fallout in cave development in a travertine deposit - Evidence from sulfur and oxygen isotopes. Chemical Geology, 49 (1-3): 205-211. http://dx.doi.org/10.1016/0009-2541(85)90156-1

van Hengstum P., Richards D., Onac B.P. \& Dorale J.A., 2014 - Coastal caves and sinkholes. In: Shennan I., Long A. \& Horton B. (Eds.), Handbook for sea-level research. London: John Wiley \& Sons: in press.

Van Norstrand R.A., Hettinger W. P. \& Keith C.D., 1956 A new alumina trihydrate. Nature, 177: 713-714.

Vasconcelos C., McKenzie J.A., Bernasconi S., Grujic D. \& Tien A.J., 1995 - Microbial mediation as a possible mechanism for natural dolomite formation at low temperatures. Nature, 377: 220-222. http://dx.doi.org/10.1038/377220a0

Vesica P.L., Tuccimei P., Turi B., Fornós J.J., Ginés A., Ginés J., 2000 - Late Pleistocene paleoclimates and sea-level change in the Mediterranean as inferred from stable isotope and $U$-series studies of overgrowths on speleothems, Mallorca, Spain. Quaternary Science Reviews, 19: 865-879. http://dx.doi.org/10.1016/S0277-3791(99)00026-8

Wall J.R.D., Wolfenden E.B., Beard E.H. \& Deans T., 1962 - Nordstrandite in soil from West Sarawak, Borneo. Nature, 196: 264-265.

http://dx.doi.org/10.1038/196264b0

Warthmann R., van Lith Y., Vasconcelos C., McKenzie J.A. \& Karpoff A.M., 2000 - Bacterially induced dolomite precipitation in anoxic culture experiments. Geology, 28: 1091-1094.

http://dx.doi.org/10.1130/0091-7613(2000)28<1091: BIDPIA $>2.0 . \mathrm{CO} ; 2$

White W.B., 1997 - Thermodynamic equilibrium, kinetics, activation barriers, and reaction mechanisms for chemical reactions in karst terrains. Environmental Geology, 30 (1-2): 46-58.

http://dx.doi.org/10.1007/s002540050131

White W.B., Vito C. \& Scheetz B.E., 2009 - The mineralogy and trace element chemistry of black manganese oxide deposits from caves. Journal of Cave and Karst Studies, 71 (2): 136-143.

Zheng Y.-F., 1999 - Oxygen isotope fractionation in carbonate and sulfate minerals. Geochemical Journal, 33: $109-126$.

http://dx.doi.org/10.2343/geochemj.33.109 